\title{
WASTE-TO-FUEL OPPORTUNITIES FOR BRITISH QUICK SERVICE RESTAURANTS: A CASE STUDY
}

Anthony Velazquez Abad (corresponding author)

Transportation Research Group, Engineering and the Environment, University of Southampton, Southampton. SO17 1BJ. United Kingdom. Phone: +44 (0)23 80593316 Fax: +44 (0)23 80593152

E-Mail: A.Velazquez@soton.ac.uk

\section{Tom Cherrett}

Transportation Research Group, Engineering and the Environment, University of Southampton, Southampton. SO17 1BJ. United Kingdom. Phone: +44 (0)23 80594657 Fax: +44 (0)23 80593152

E-Mail: t.j.cherrett@soton.ac.uk

\begin{abstract}
The fast food supply chain is facing increasing operating costs due to volatile food and energy prices. Based on a case study of a major fast food logistics operator, this paper quantifies the potential for fuel generation from the waste generated by quick-service restaurants in Britain. Several fuel pathways and supply chains were mapped to understand the carbon intensity of the various waste-to-fuel opportunities, the number of heavy goods vehicles that might be powered and the key factors that could help companies make better informed decisions related to fuel generation from waste.
\end{abstract}

The research suggested that depending on the scenarios considered, between 13.9 and17.2 million GJ of energy could be obtained from fuels made from the waste arisings of British quick service restaurants and their distribution centres (DCs), representing between 4.4 and $5.8 \%$ of the national energy consumption from heavy goods vehicles (HGVs) and Well-to-Wheel (WTW) Greenhouse Gases (GHG) savings of between 652 898 thousand tonnes of $\mathrm{CO}_{2}$ equivalent annually.

Used cooking oil and burger fat arising from British quick-service restaurants could generate enough energy to power up to 3,891 HGVs with FAME diesel (B100), 1,622 with HVO diesel (B100) or 1,943 with biomethane annually. The paper and card generated by these same establishments could also power an additional 4,623 biomethane vehicles, wood pallets could power an additional 73 bioethanol trucks and plastics could also power 341 vehicles running with synthetic diesel.

The results showed that collections of separate waste fractions by logistics operators could make a relevant contribution towards the decarbonisation of the supply chain while reducing disposal fees and fuel costs. The carbon emissions resulting from this approach depend greatly on the footprint of the collection and transportation systems used to move waste from the restaurants to the processing plants and return the converted fuel back to the distribution centres where the vehicles are refuelled. Logistics firms are in a privileged position to manage these flows as they can use empty back-haul trips to collect and consolidate waste in distribution centres.

\section{Keywords}

Biomass; fuel; energy; GHG; restaurant; waste 
The economic recession has forced supply chain operators across the EU to reassess their operations in order to remain competitive. Customers are also becoming more sensitive toward issues of sustainability, and organisations must reconcile these concerns with their triple bottom line (people, planet and profit) as a way to improve stakeholders' loyalty (Elkington, 1998). Rising food prices coupled to volatile energy prices and concerns related to environmental sustainability and energy security have led to increased interest in how to maximise the use of existing resources, particularly the waste-to-fuel opportunities arising from the food supply chain. According to Hollins (2013), UK hospitality and food service outlets only recycle, send to anaerobic digestion (AD) or compost $46 \%$ of the 2.87 million tonnes of waste generated each year. Designing products for a circular economy could allow UK supply chains to become virtually waste free whilst generating an income stream of $\$ 1.5$ billion (equivalent to approx. $£ 0.9$ bn. as of $31 / 12 / 2013$ ) per year or around $\$ 172$ ( $£ 104$ as of 31/12/2013) profit per tonne of food waste (Ellen MacArthur Foundation, 2013). This paper uses a detailed investigation of a British fast food supply chain (FFSC) to understand the nature of the co-products and byproducts produced, how these are currently treated, and the scope for their secondary utilisation in the operation of logistics fleets.

\subsection{The British Fast Food Supply Chain}

Quick service restaurants (QSRs) account for $12.1 \%$ of hospitality sector outlets in the United Kingdom (UK) (WRAP, 2011) and generate annual revenues in the region of $£ 5.5 \mathrm{bn}$ (IBISWorld, 2013). They are responsible for generating 246,000 tonnes of waste annually with less than $57 \%$ of this being recycled, reused or composted (WRAP, 2011). Hollins (2013) estimated the total food waste of UK QSRs in 76,000 tonnes (including fast food, take-aways, fish and chip shops and sandwich bars), representing $£ 277$ million per year (at $£ 3,500 /$ tonne) from which just 17,000 tonnes were unavoidable. With retail diesel costs having increased by almost $40 \%$ from 2004 to 2014 (DECC, 2015), there is growing interest in whether waste arisings can be used as a supplementary fuel, given that biofuels have been shown to deliver substantial greenhouse gas (GHG) emissions savings, avoiding negative indirect land use changes and relieving pressures on food prices. The whole UK food chain emitted around 115 million tonnes of $\mathrm{CO}_{2}$ eq. in $2009^{1}$ (Defra, 2011) with the commercial transportation of food for UK consumption representing around 9\% of these GHGs emissions (Defra, 2011) and between 1.8\% (FRPERC et al. , 2010, Smith et al. , 2005) and 2.5\% (Garnett, 2003) of total UK carbon emissions.

\subsection{Waste Streams}

QSRs typically operate separate waste collections for paper and card, plastics, used cooking oil (UCO) and grease trap waste (GTW), kitchen food waste, glass and wood among other fractions. Waste arisings at QSRs also result from damage to products during handling, storage and transportation as well as from products discarded by customers. A survey conducted by WRAP (2011) reported that mixed waste from UK QSRs generally consisted of kitchen food waste (51\%), paper (15.1\%), card (8.6\%), dense plastics (4.8\%), plastic film $(6 \%)$ and glass (3\%). It was estimated that UK QSRs produced around 16,300 tonnes of paper and 9,200 tonnes of card as mixed waste in 2009 (WRAP, 2011). Thermoplastics are widely used in the FFSC as packaging, and UK QSRs produced around 5,200 tonnes of dense plastic and 6,300 tonnes of plastic film in 2009 (WRAP, 2011).

In 2009, the UK food chain produced 15 million tonnes of drink and food waste, almost half coming from households, 3.2 million from manufacturing and 0.6 million linked to the UK hotel and catering sectors (Defra, 2011). From the 54,700 tonnes of food waste produced by QSRs ( $0.3 \%$ of the total) 15,500 tonnes were avoidable (WRAP, 2011). To put this into perspective, Tesco generated 28,500 tonnes of food waste in the first two quarters of 2013, mainly from bakery products and fruit and vegetables (Houses of Parliament, 2013).

In Europe, an estimated $14.6 \%$ of meat and $19 \%$ of fish are wasted between distribution and point of consumption (Gustavsson et al. , 2011); Defra's estimate for the UK is considerably lower and suggested that $13 \%$ of edible meat and fish are wasted (Defra, 2013a). The UK produces around 14 billion litres of milk annually (C-Tech Innovation Ltd, 2004) and over 1 billion litres (7\%) are estimated to be wasted along with $26.5 \%$ of cereals, $23 \%$ of potatoes and $27 \%$ of fruit and vegetables between distribution and consumption (Gustavsson, Cederberg, 2011).

In Europe, the main oil crops are sunflower and rape seed (C-Tech Innovation Ltd, 2004) which are the main ingredients in the vegetable cooking oils used by one of the leading UK fast food supply chains. British QSRs generate significant amounts of UCO with Kentucky Fried Chicken (KFC) collecting $7.75 \mathrm{~m}$ litres

\footnotetext{
${ }^{1}$ Excluding overseas production, food packaging, food waste and land use change.
} 
annually (KFC, 2012) and McDonalds over 3.6 m litres (McDonald's, 2012), not including GTW from wastewater interceptors or separately collected burger fat. More efficient cooking technologies such as air fryers and healthier meal options may reduce the availability of UCO in the future, with Burger King and McCain having already introduced fries with 40\% less fat in 2013 (Burger King, 2013).

\subsection{Waste-to-Fuel Opportunities for British QSRs}

Biogas is typically obtained from $\mathrm{AD}$ or landfill gas recovery from organic waste feedstocks such as fish, meat, fruit, vegetables, dairy products, wasted oil, fat, paper and cardboard. In August 2011, there were 66 plants in the UK treating around 1 million wet tonnes of food and agricultural waste (Houses of Parliament, 2011); this increased to 78 plants by June 2012 (NNFCC, 2012). To convert this biofuel into biomethane compatible with CNG (compressed natural gas) trucks, the biogas needs to be upgraded to $95 \%$ methane, venting or capturing the $\mathrm{CO}_{2}$ by-product. Biomethane as a fuel for transportation is gaining popularity, with three of the 23 LNG (liquid natural gas) and three of the 8 CNG dedicated refuelling facilities currently registered in the UK using biogenic content (Gas Vehicle Hub, 2014). Alternatively, energy producers can use biomethane in combined heat and power plants (CHP) to reduce their energy costs and GHG emissions. When the fuel is generated through $\mathrm{AD}$, the residue of the process (digestate) can also be used as a biological fertilizer reducing the need for synthetic fertilizers (Banks et al. , 2011, Heaven et al. , 2011). If the digestate complies with the requirements of the Publicly Available Specification BSI (PAS) 110, it is no longer considered a waste and does not attract disposal costs.

The paper industry generates pulpwood waste, black liquor and coke from the paper Kraft process and there is potential for producing methane from these wastes (Lin et al. , 2011, Magnusson and Alvfors, 2012, Rintala and Puhakka, 1994) with some large paper manufacturing companies installing CHP plants to use the biogas obtained from their recycling processes (Saica Natur, 2012). Besides AD, energy efficient recovery pathways for paper, cardboard and wood waste (pallets) include combustion and incineration with heat recovery and at a smaller scale, gasification and pyrolysis of ligno-cellulosic waste. Gasification is more appropriate in applications where there is a use for heat while pyrolysis is typically used to transform biomass into liquid fuels (Panwar et al. , 2012). The char produced during pyrolysis can also be gasified to produce syngas which is energy-rich in hydrogen, methane, monoxide of carbon and other compounds. GHG savings of $98 \%$ have been reported by using black liquor from waste wood as feedstock from the paper industry (Edwards et al. , 2014). The Conservation of Clean Air and Water in Europe (CONCAWE) report estimates that synthetic diesel can yield GHG savings of $97 \%$ by using the Fischer-Tropsch approach (Edwards, Larive, 2014). This gas-to-liquids chemical process converts a mix of gases (monoxide of carbon and hydrogen) into liquid hydrocarbons (Damartzis and Zabaniotou, 2011). Currently, the only Biomass-to-Liquid (BTL) initiative in the UK is a pilot plant producing biobutanol (Bioenergy2020+, 2013), a fuel that can be blended with petrol. As the majority of the HGV fleet in the UK runs on diesel, there is very little scope for making any impact on this specific market in the short term.

UCO from the food industry is widely recycled in the UK and constitutes one third of all Fatty Acid Methyl-Ester (FAME) biodiesel feedstock (DfT, 2013a). In the UK, there are 30 registered medium and large UCO collectors and biodiesel producers (organisations with more than 50 employees) with the capacity to process 250 million litres of UCO per year (Environmental Audit Committee, 2012). First generation biodiesel converts UCO into FAME biodiesel through transesterification; however, current commercial second generation biodiesels convert UCO into hydrogenated vegetable oils biodiesel (HVO), obtaining bio propane as a coproduct (DECC, 2014a). Sunde et al. (2011) found that HVO made from UCO outperforms FAME biodiesel and BTL biodiesel from woody material, with respect to environmental life cycle impact and costs. FAME biodiesel from UCO can deliver $84 \%$ GHG savings (WOFA3 pathway) compared to $91 \%$ for HVO biodiesel (Edwards, Larive, 2014). Unfortunately, there are currently no second generation commercial biodiesel production plants in the UK. A summary of the GHG savings that could be realised from using different biofuels made from QSR waste feedstocks is shown in Table 1.

Most plastics and films come from fossil oils and can be recycled a number of times into new plastics avoiding the production of new virgin plastic. They can also be converted into hydrocarbon fuels (Kaminsky et al. , 2004, Michaud et al. , 2010) with each tonne of mixed plastic yielding between 700 litres (SITA UK, 2011) and 1,201 litres of consumer ready diesel (4R Sustainability Inc., 2011) depending on whether other oil distillates are also obtained in the process. In the UK, SITA plans to open 10 processing plants with the capacity to recover energy from 60,000 tonnes of mixed plastic waste per year, resulting in a diesel with a higher cetane number and at a lower cost (SITA UK, 2011). The GHG emission factor for recycled plastic is $0.6 \mathrm{~kg} \mathrm{CO} 2 \mathrm{eq} . / \mathrm{kg}$ versus 2.5-4.5 $\mathrm{kg} \mathrm{CO}_{2}$ eq./kg for new plastic (Hill et al. , 2013). For this reason, it is not widely considered optimal to produce synthetic fuel from plastics that have not reached their end of life as this would reduce the availability of recycled plastic, forcing companies to buy products made from virgin material. Another 
alternative to reduce emissions from plastic consumption is increasing the proportion of bioplastics in packaging; however, this is not always technically feasible. Bioplastics can protect firms against rising prices of mineral oil derived plastics as some of them can also be digested to produce biogas, a preferred option over composting in respect to energy demand and depletion of natural resources (Michaud, Farrant, 2010).

Table 1 GHG balances for different fuel and biofuel pathways. Adapted from: Edwards, Larive (2014)

\begin{tabular}{|c|c|c|c|c|c|c|}
\hline $\begin{array}{c}\text { Pathway } \\
\text { Code }\end{array}$ & Feedstock & Fuel & $\begin{array}{c}\text { Total WTT } \\
\text { GHG } \\
\text { (g CO} 2 \text { eq./MJ } \\
\text { final fuel) }\end{array}$ & $\begin{array}{c}\text { Total TTW } \\
\text { GHG } \\
\text { (g CO} 2 \text { eq./MJ } \\
\text { final fuel) }\end{array}$ & $\begin{array}{c}\text { Total WTW } \\
\text { GHG (incl. } \\
\text { combustion) } \\
\text { (g CO } \mathrm{CO}_{2} \text { eq./MJ } \\
\text { final fuel) }\end{array}$ & $\begin{array}{l}\text { GHG } \\
\text { Savings } \\
\text { (\%) vs. } \\
\text { Baseline }\end{array}$ \\
\hline COD1 & $\begin{array}{l}\text { Mineral } \\
\text { Oil }\end{array}$ & Diesel & 13.8 & 74.8 & 88.6 & $\begin{array}{l}\text { Baseline } \\
\text { Diesel } \\
\text { Pathway }\end{array}$ \\
\hline COG1 & $\begin{array}{l}\text { Mineral } \\
\text { Oil }\end{array}$ & Gasoline & 12.2 & 74.9 & 87.1 & $\begin{array}{l}\text { Baseline } \\
\text { Gasoline } \\
\text { Pathway }\end{array}$ \\
\hline GMCG1 & $\begin{array}{l}\text { Mineral } \\
\text { Gas }\end{array}$ & $\begin{array}{l}\text { CNG (EU- } \\
\text { Mix) }\end{array}$ & 11.8 & 57.5 & 69.3 & $\begin{array}{l}\text { Baseline } \\
\text { Gas } \\
\text { Pathway }\end{array}$ \\
\hline OWCG1 & $\begin{array}{l}\text { Municipal } \\
\text { Waste }\end{array}$ & $\begin{array}{l}\text { Compressed } \\
\text { Biogas }\end{array}$ & 11.3 & 3.5 & 14.8 & $\begin{array}{l}83 \% \text { vs. } \\
\text { COD1 } \\
79 \% \text { vs. } \\
\text { GMCG1 } \\
\end{array}$ \\
\hline WWET1 & $\begin{array}{l}\text { Waste } \\
\text { Wood }\end{array}$ & $\begin{array}{l}\text { Ethanol } \\
\text { (Gasoline) }\end{array}$ & 19.3 & 0.2 & 19.5 & $\begin{array}{l}77.6 \% \\
\text { vs. } \\
\text { COG1 }\end{array}$ \\
\hline WOFA3a & $\begin{array}{l}\text { Waste } \\
\text { Cooking } \\
\text { Oil (UCO) }\end{array}$ & $\begin{array}{l}\text { FAME } \\
\text { Diesel }\end{array}$ & 13.6 & 0.2 & 13.8 & $\begin{array}{l}84 \% \text { vs. } \\
\text { COD1 }\end{array}$ \\
\hline WOHY1a & $\begin{array}{l}\text { Waste } \\
\text { Cooking } \\
\text { Oil (UCO) }\end{array}$ & HVO Diesel & 13.0 & -4.9 & 8.1 & $\begin{array}{l}91 \% \text { vs. } \\
\text { COD1 }\end{array}$ \\
\hline TOFA3a & Tallow & $\begin{array}{l}\text { FAME } \\
\text { Diesel } \\
\end{array}$ & 26.2 & 0.1 & 26.30 & $\begin{array}{l}70 \% \text { vs. } \\
\text { COD1 }\end{array}$ \\
\hline TOHY1a & Tallow & HVO Diesel & 29.7 & -5.2 & 24.50 & $\begin{array}{l}72 \% \text { vs. } \\
\text { COD1 }\end{array}$ \\
\hline
\end{tabular}

\section{Methodology}

The study was based on a substantial database of waste collection movements from a major global fast food chain, comprising 34 months of separated waste collections from January 2012 to October 2014 from more than 1,000 British QSRs and their associated DCs.

The most realistic waste-to-fuel pathways based on the case study were estimated using the current EU waste-to-fuel production infrastructure and the most feasible HGV powertrain technologies. The potential yields (Table 2) along with the analysis of the waste collection data, were used to produce an annual waste profile for each restaurant. This waste profile was then extrapolated to the total number of British QSRs $(39,762)$ providing an estimate of the waste-to-fuel potential across the sector.

\subsection{Categories of Waste}

An analysis of the case study organisation showed the main waste types at different stages of its supply chain (Figure 1). The segregated waste fractions considered in this study included waste streams produced by the restaurants such as UCO, burger fat, cardboard, plastic films and bottles, and food waste from the kitchens. Data were also collected on the separate collections of food waste, wooden pallets, plastic film, cardboard and paper from the DCs. The WRAP report (WRAP, 2011) estimated that British QSRs produce around 246,000 tonnes of waste per year. According to our analysis, this figure is a serious underestimate as just separate collecions of cardboard already represent more than double this amount. The main reasons for this, as suggested in their 
methodology, was their lack of access to data from large corporations and the small sample size. This study, on the other hand, has managed to access data representing over a thousand QSRs with accurate data of the total tonnage of waste fractions collected separately sent to recycling; however the fractions with no real potential for producing transportation fuels, were not included in the analysis.

Table 2 Energy yields from different feedstocks and pathways. Assuming that $\rho$ of methane is $726.3 \mathrm{~kg} / \mathrm{m}^{3} \mathrm{and}$ conventional diesel $\rho=839.6 \mathrm{~kg} / \mathrm{m}^{3}$.

\begin{tabular}{|c|c|c|c|c|c|}
\hline $\begin{array}{l}\text { Pathway } \\
\text { Code }\end{array}$ & $\begin{array}{c}\text { Waste } \\
\text { Feedstock }\end{array}$ & Fuel & Conversion Factors & 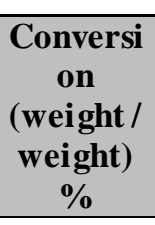 & Literary Source \\
\hline \multirow{2}{*}{ WOFA3a } & \multirow{4}{*}{$\mathrm{UCO}$} & \multirow{2}{*}{ FAME } & $\begin{array}{l}0.96 \text { tonnes (output)/tonnes } \\
\text { (input) refining }\end{array}$ & \multirow{2}{*}{$90.91 \%$} & \multirow{2}{*}{$\begin{array}{l}\text { E4Tech and } \\
\text { Concepto (2013) } \\
*\end{array}$} \\
\hline & & & $\begin{array}{l}0.947 \text { tonnes (output)/tonnes } \\
\text { (input) transesterification }\end{array}$ & & \\
\hline \multirow{2}{*}{ WOHY1a } & & \multirow{2}{*}{ HVO } & $\begin{array}{l}0.405 \text { tonnes (output)/tonnes } \\
\text { (input) refining }\end{array}$ & \multirow{2}{*}{$32.04 \%$} & \multirow{2}{*}{$\begin{array}{l}\text { E4Tech and } \\
\text { Concepto }(2013 *\end{array}$} \\
\hline & & & $\begin{array}{l}0.791 \text { tonnes (output)/tonnes } \\
\text { (input) hydrogenation }\end{array}$ & & \\
\hline \multirow{2}{*}{ WOCG1 } & $\begin{array}{l}\text { Used Vegetable } \\
\text { Oil }\end{array}$ & \multirow{2}{*}{$\begin{array}{l}\text { Bio- } \\
\text { Methane }\end{array}$} & $0.6485 \mathrm{~m}^{3} / \mathrm{kg}$ VS added & $47.10 \%$ & $\begin{array}{l}\text { Labatut et al. } \\
(2011) *\end{array}$ \\
\hline & $\begin{array}{l}\text { Waste Edible } \\
\text { Oil }\end{array}$ & & $1.104 \mathrm{~m}^{3} / \mathrm{kg} \mathrm{VS}$ added & $80.18 \%$ & $\begin{array}{l}\text { Braun et al. } \\
(2003)\end{array}$ \\
\hline \multirow[b]{2}{*}{ TOFA3 } & \multirow{4}{*}{$\begin{array}{l}\text { Burger fat } \\
\text { (Tallow) }\end{array}$} & \multirow[b]{2}{*}{ FAME } & $\begin{array}{l}0.96 \text { tonnes (output)/tonnes } \\
\text { (input) refining }\end{array}$ & \multirow[b]{2}{*}{$90.91 \%$} & \multirow{2}{*}{$\begin{array}{l}\text { E4Tech and } \\
\text { Concepto (2013) } \\
*\end{array}$} \\
\hline & & & $\begin{array}{l}0.947 \text { tonnes (output)/tonnes } \\
\text { (input) transesterification }\end{array}$ & & \\
\hline \multirow{2}{*}{ TOHY1a } & & \multirow{2}{*}{ HVO } & $\begin{array}{l}0.405 \text { tonnes (output)/tonnes } \\
\text { (input) refining }\end{array}$ & \multirow{2}{*}{$32.04 \%$} & \multirow{2}{*}{$\begin{array}{l}\text { E4Tech and } \\
\text { Concepto (2013) } \\
*\end{array}$} \\
\hline & & & $\begin{array}{l}0.791 \text { tonnes (output)/tonnes } \\
\text { (input) hydrogenation }\end{array}$ & & \\
\hline TACG1 & $\begin{array}{l}\text { Animal fat } \\
\text { (Tallow) }\end{array}$ & $\begin{array}{l}\text { Bio- } \\
\text { Methane }\end{array}$ & $1.0 \mathrm{~m}^{3} / \mathrm{kg} \mathrm{VS}$ added & $72.63 \%$ & $\begin{array}{l}\text { Braun et al. } \\
(2003)^{*}\end{array}$ \\
\hline \multirow{2}{*}{ FFCG1 } & \multirow{2}{*}{$\begin{array}{l}\text { Fast Food } \\
\text { Waste }\end{array}$} & \multirow{2}{*}{$\begin{array}{l}\text { Bio- } \\
\text { Methane }\end{array}$} & $0.693 \mathrm{~m}^{3} / \mathrm{kg} \mathrm{VS}$ added & $50.33 \%$ & $\begin{array}{l}\text { Braun et al. } \\
(2003)\end{array}$ \\
\hline & & & $\begin{array}{l}0.473 \mathrm{~m}^{3} / \mathrm{kg} \text { VS added } \\
\text { (pasteurised sample) }\end{array}$ & $34.35 \%$ & $\begin{array}{l}\text { Banks and Zhang } \\
(2010)^{*}\end{array}$ \\
\hline CACG1 & Cardboard & $\begin{array}{l}\text { Bio- } \\
\text { Methane }\end{array}$ & $\begin{array}{l}0.267 \mathrm{~m}^{3} / \mathrm{kg} \text { VS added } \\
\text { (pasteurised sample) }\end{array}$ & $19.39 \%$ & $\begin{array}{l}\text { Banks and Zhang } \\
(2010)^{*}\end{array}$ \\
\hline PACG1 & Office Paper & $\begin{array}{l}\text { Bio- } \\
\text { Methane }\end{array}$ & $0.137 \mathrm{~m}^{3} / \mathrm{kg}$ VS added & $9.95 \%$ & $\begin{array}{l}\text { Banks and Zhang } \\
(2010)^{*}\end{array}$ \\
\hline \multirow{2}{*}{ WWET1 } & \multirow{2}{*}{ Wooden Pallets } & \multirow{2}{*}{$\begin{array}{l}\text { Bio- } \\
\text { ethanol }\end{array}$} & $\begin{array}{l}0.98 \text { tonnes (output)/tonnes } \\
\text { (input) wood crushing }\end{array}$ & \multirow{2}{*}{$16.27 \%$} & \multirow{2}{*}{$\begin{array}{l}\text { E4Tech and } \\
\text { Concepto (2013) } \\
*\end{array}$} \\
\hline & & & $\begin{array}{l}0.166 \text { tonnes (output)/tonnes } \\
\text { (input) production }\end{array}$ & & \\
\hline PFSD & $\begin{array}{l}\text { Plastic Film } \\
\text { (LDPE) }\end{array}$ & \multirow{2}{*}{$\begin{array}{l}\text { Synthetic } \\
\text { Diesel } \\
\text { EN590 }\end{array}$} & \multirow{2}{*}{$\begin{array}{l}\text { Between } 750 \mathrm{~L} / \text { tonne (Cynar } \\
\text { Plc) and 950L/tonne (Klean } \\
\text { Industries) }\end{array}$} & \multirow{2}{*}{$\begin{array}{l}\text { Average } \\
73.32 \%\end{array}$} & \multirow{2}{*}{$\begin{array}{l}\text { Adapted from: } \\
\text { 4R Sustainability } \\
\text { Inc. }(2011) *\end{array}$} \\
\hline PBSD & $\begin{array}{l}\text { Plastic Bottles } \\
\text { (HDPE) }\end{array}$ & & & & \\
\hline
\end{tabular}




\begin{tabular}{|c|c|c|c|c|c|}
\hline \multirow[t]{2}{*}{ TYPE WASTE } & \multicolumn{2}{|c|}{ PRODUCTION } & \multirow[t]{2}{*}{ PROCESSING } & \multirow[t]{2}{*}{ DISTRIBUTION } & \multirow[t]{2}{*}{ QUICK SERVICE RESTAURANTS } \\
\hline & Meat, Fish \& Dairy & Agriculture \& Other & & & \\
\hline \multirow{2}{*}{$\begin{array}{l}\text { Organic Losses } \\
\text { \& Waste }\end{array}$} & $\begin{array}{l}\text { Dead Animals } \\
\text { Manure }\end{array}$ & $\begin{array}{l}\text { Mechanically Damaged } \\
\text { parts \& Seed Losses }\end{array}$ & $\begin{array}{l}\text { Non-commercial Parts } \\
\text { By-products: Tallow, Oil } \\
\text { cake, Fish Meal }\end{array}$ & $\begin{array}{l}\text { Out of Date Food } \\
\& \text { Expired Promotions }\end{array}$ & $\begin{array}{l}\text { Used Cooking Oil, Fat, Coffee } \\
\text { Grounds } \\
\text { \& Food Leftovers }\end{array}$ \\
\hline & $\begin{array}{l}\text { Paper \& Cardboard } \\
\text { Pallets }\end{array}$ & Hard parts of Plants & $\begin{array}{l}\text { Paper \& Cardboard } \\
\text { Wooden Pallets }\end{array}$ & $\begin{array}{l}\text { Paper \& Cardboard } \\
\text { Wooden Pallets }\end{array}$ & $\begin{array}{l}\text { Paper \& Cardboard Packaging } \\
\text { \& Cups }\end{array}$ \\
\hline $\begin{array}{l}\text { Other Orga nic } \\
\text { Waste } \\
\text { (Effluents) }\end{array}$ & Sludges & $\begin{array}{l}\text { Cleaning Water } \\
\text { (Vegetables) }\end{array}$ & $\begin{array}{l}\text { Blanching, CIP Cleaning } \\
\text { \& Water Effluent }\end{array}$ & $\begin{array}{l}\text { Cleaning Water } \\
\text { Interceptors }\end{array}$ & $\begin{array}{l}\text { Drinks, Ice Creams } \\
\& \text { Cleaning Water }\end{array}$ \\
\hline $\begin{array}{l}\text { Non Organic } \\
\text { Losses \& Waste }\end{array}$ & Plastic \& Film Packaging & $\begin{array}{l}\text { Plastic \& Film } \\
\text { Packaging }\end{array}$ & Plastic \& Film Packaging & Plastic \& Film Packaging & $\begin{array}{l}\text { Plastic \& Film Packaging, } \\
\text { Plastic Cutlery \& Bottles }\end{array}$ \\
\hline
\end{tabular}

Figure 1 Main waste streams in the fast food supply chain with waste-to-fuel potential.

The wastes that the FFSC can convert into usable fuels for transportation were classified into three main categories: organic waste, non-organic waste and water effluent. Organic waste includes animal losses and manure, damaged vegetables, by-products of processing and rendering such as tallow, oil seed cake, bone meal as well as out of date food from DCs and food wastage from restaurants. UCO and fat from cooked burgers and lingo-cellulosic wastes are also included in this category. The latter comprises non-edible parts of plants, card and paper used in packaging and food containers, and wooden pallets used in transportation. Non-organic waste comprises mainly packaging film, plastic cases for transportation of goods and plastic bottles for drinks. A category for waste effluent was also included as this typically goes into the foul drain and ends in water treatment plants where organic effluents are treated producing biogas as a by-product.

Due to the limitations of this study, the boundaries were setup between distribution and QSRs. Waste streams from production and processing were excluded and the authors acknowledge some limitations in the methodological approach as a result. The quantitative analysis of over 1000 QSRs (around 2.5\% of the British market) may not represent the waste profile of QSRs specialised in other types of foods. Future research could benefit from surveying and characterising other franchises and QSR waste to reveal a more precise waste profile. This study excludes fish and chip shops because they are not classified as 'fast food restaurants and takeaways' by the Ordnance Survey geographical information dataset used in this research and access to segregated data for waste collections from such shops were not available.

\subsection{Data Anal ysis}

Accurate monthly waste tonnage data from QSRs and DCs were supplied by a third party logistics provider (3PL) managing the supply chain for the case study organisation from January 2012 to October 2014, with additional data provided by a third party waste management organisation. The total tonnage was divided by the number of restaurants to provide a mean waste profile per restaurant and year. This profile was extrapolated to the total number of fast food outlets in Great Britain, considered to be 39,762 according to data supplied by Ordnance Survey (2014) for the class count 01020018 (fast food and takeaway outlets).

Unstructured interviews with the directors of two 3PL companies working in the fast food sector provided an insight into the challenges of waste management from an operational and legal perspective. Additional interviews were also conducted with several European truck manufacturers to ascertain the technology roadmaps of different fuel technologies and the impact of Euro 6 emissions standards on UK HGV fleets. Interviews with logistics operators and vehicle manufacturers, combined with a literature survey, allowed a range of realistic and feasible pathways for the conversion of QSR wastes into transportation fuels to be identified. 


\subsubsection{Energy Yields}

Data on the energy yields from waste feedstocks for each pathway were obtained from multiple sources (Table 2). In this study, UCO was considered to be the same as used vegetable oil and waste edible oil; and burger fat, similar to tallow or animal fat. GTW was not included in this study as there were no detailed data related to interceptor's collections tonnage. The calculations made took into consideration the conversion factors appearing with an asterisk (*) in Table 2. FAME represents feedstocks that have been converted into biodiesel through the transesterification process; also known as first generation biofuel, with HVO biodiesel being obtained through hydrogenation known as second generation biodiesel. Bio methane is typically obtained through $\mathrm{AD}$. The biomethane production potential from feedstock was calculated either as a main substrate or as a co-substrate (Table 2). Woodchips can be converted into biomethanol or bioDME (dimethyl ether) through gasification; however it is also possible to produce bioethanol, biogasoline and biodiesel through enzyme hydrolysis fermentation yielding more advanced second generation biofuels but at a higher expense than conventional fuels. Examples of commercial stage plants in Europe for these pathways are only found in Nordic countries (BioDME, 2012, Sekab, 2013). Pyrolysis is also the main process to produce synthetic diesel from plastics. The conversion efficiency factor used in this study for plastic-to-fuel corresponds to the average of the values reported by a number of companies working in the sector as reflected in the 4R Sustainability Inc. (2011) survey.

To convert litres of UCO and tallow into $\mathrm{kg}$, the yearly production was converted to $\mathrm{kg}$ assuming that both have a density of $0.92 \mathrm{~kg} / \mathrm{L}$ and a density for FAME biodiesel of $0.89 \mathrm{~kg} / \mathrm{L}$ and $0.78 \mathrm{~kg} / \mathrm{L}$ for HVO biodiesel. Also, based on the values reported by Edwards, Larive (2014), the densities of bioethanol and synthetic diesel considered were $0.794 \mathrm{~kg} / \mathrm{L}$ and $0.78 \mathrm{~kg} / \mathrm{L}$ respectively.

\subsubsection{Well-to-Wheel Carbon Accounting of Waste-to-Fuels}

The GHG emissions of growing or producing waste feedstocks are attributed to the QSR chains that procured them. The Well-to-Wheel (WTW) GHG emissions included are the sum of Well-to-Tank and Tank-to-Wheel emissions. Tank-to-Wheel (TTW) emissions are those emitted while consuming (burning) the fuels. The TTW emission factors and densities used in this study for each final fuel are the ones reported by Edwards, Larive (2014) in the CONCAWE report (Table 1). In this case, Well-to-tank (WTT) emissions are those emitted as a result of all the processes that make possible the conversion of waste into fuel. These include the collection, transportation, storage, manipulation, handling, and conversion of feedstock (waste) into fuel, and its subsequent transportation, storage, manipulation, handling and dispensing. The WTT carbon intensities and energy yields were calculated with the assistance of the UK Carbon Calculator (E4Tech and Concepto, 2013) using the energy yields marked with an asterisk $(*)$ in Table 2 . Transportation emissions represent a significant contribution to overall WTT GHG emissions. When moving liquid or solid feedstocks, appropriate liquid/bulk freight vehicles and vessels were assumed and their TTW emissions were the default options in the UK Carbon Calculator (E4Tech and Concepto, 2013), unless specified otherwise.

GHG reporting depends on carbon accounting practices, the emissions factors of each energy pathway and year, and the total fuel consumed. When information regarding the latter is not available, the UK carbon reporting methodology followed by DECC (2014b) makes assumptions regarding driving cycles and loading factors. In this study, as the exact quantity of fuel consumed by the QSR fleet was known, it was possible to calculate the WTW GHG emissions directly without need to evaluate driving cycles, vehicle types or loading factors. It was assumed that during back-haul trips, each delivery truck was empty and the carbon emissions of waste collections made by the 3PL fleet were almost negligible, contributing just marginally to the fuel consumption due to the increase in vehicle mass compared to an otherwise empty back-haul trip.

\subsubsection{Geographical Data and Geographic Information Systems}

The UK Carbon Calculator allows the parameterisation of distances and modes of transport as well as energy requirements associated with intermediate waste-to-energy processes (e.g. transportation, handling, processing, storage and refuelling) and emission factors of the national energy grid. The distances between QSRs and DCs were taken as the averages observed for the case study supply chain as shown by the routing and scheduling software and using shortest-path algorithms for the whole year. As a typical trip was around $280 \mathrm{~km}$, this means that the return trip is half of this and as around 4 deliveries are undertaken, it was considered that $35 \mathrm{~km}$ can be attributed to each restaurant. Distances between the DCs and fuel processing plants were calculated using Google Maps (2013) for all road haulage trips. When waste was shipped abroad for processing, the port of origin was taken to be Felixstowe, the port of destination was the one closest to the location of the waste processing plant and the distances were obtained using Searates.com (2013). The location of British QSRs were obtained from Ordnance Survey (2014), Figure 2. The transport related energy consumed by HGVs for each 
British district was obtained from the sub-national road transport fuel consumption dataset produced by DECC (2013). Both datasets were combined to create a map with ArcGIS illustrating the percentage fuel equivalent consumed by HGVs that could be replaced by fuels produced from the waste streams from QSRs according to different operating scenarios.

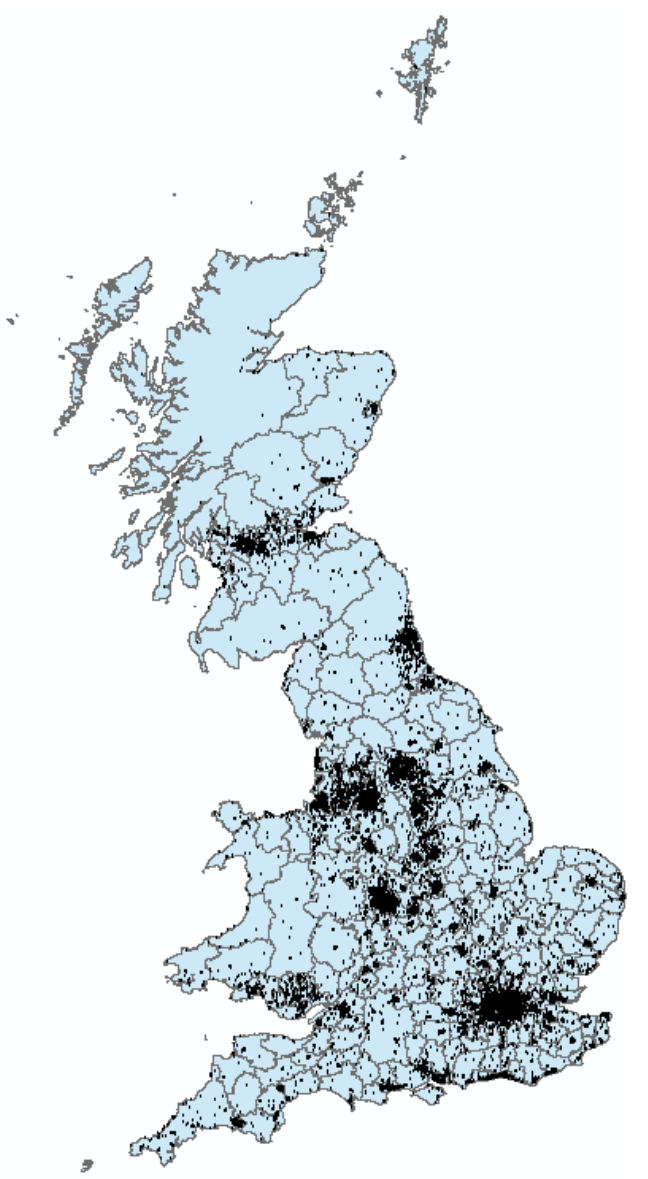

Figure 2 The distribution of the 39,762 fast food and takeaways restaurants in the Great Britain (2013).

\section{Results \\ 3.1 Feasible Waste-to-fuel Pathways for British FFSCs}

The main waste-to-fuel pathways for this supply chain and the HGV engine technologies that can be powered by these are shown in Table 3. There are two main types of powertrains: internal combustion engines (ICE) and electric motors. ICE diesel engines are the standard among UK HGV fleets (DECC, 2013) but there is a growing interest among logistics operators in ICE CNG trucks, vehicles that are also compatible with biomethane, as they can lead to substantial cost and GHG savings. Other ICE engine technologies such as BioDME or Biomethanol also appear in Table 3; however, such HGVs are currently only being tested in small-scale trials by Volvo (BioDME, 2012). HGVs powered by electric motors can use the fuels identified in this study to derive energy by using fuel cells directly or by obtaining electricity from CHP or waste-fired power plants. Solid oxide fuel cells (SOFC) produce energy from the reformation of hydrocarbon fuels (e.g. diesel/biodiesel, biomethane); however these powertrains are still only at a research stage and are currently being developed for auxiliary power units (DESTA Consortium, 2014, TOPSOE, 2010). Proton exchange fuel cell (PEMFC) powertrains use the hydrogen obtained from the gasification of biomass to transform energy into electricity with some examples of such HGV technology being found in the port drayage sector (Vision Industries Corporation, 2012).

Some engine technologies can also reduce GHG emissions through the combination of fuels or hybridisation of powertrains. Typically, dual fuel vehicles use a mix of diesel and methane (or biodiesel/biomethane) and bi-fuel trucks can use either of them but not both simultaneously. Hybrid series or parallel powertrain HGVs typically combine an internal combustion engine with an electric motor powered by a battery pack and are best suited for urban logistics, where frequent stop-start operations maximise fuel savings. Currently, the hybrid HGVs found during this research can reach up to 40 tonnes gross vehicle weight such as the e-Highway HGVs developed by Siemens (2014). Alternatively, any of the fuels obtained from waste can be converted into renewable power in CHP plants, allowing the use of electric plug-in HGVs with very low carbon 
emissions. Any of the waste feedstocks originating in the FFSC can yield a broad range of fuels depending on the pathway followed (Table 3), as well as other potentially valuable by-products. The production of FAME biodiesel and of biomethane are the simplest pathways to produce renewable fuels in the UK due to the existence of a well-developed market for UCO and tallow collections, and the large number of AD plants. In addition, vehicles using either of these fuels meet most of the requirements of hauliers regarding power and range (Cope, 2011). Second generation biodiesel pathways were also studied; however, all commercial plants were located outside the UK and this increased GHG emissions of such pathways.

Table 3 Main waste-to-fuel pathways in the fast food supply chain and current HGV powertrain technologies that can benefit from these.

\begin{tabular}{|c|c|c|c|c|c|}
\hline Industry & Sectors & Waste Type & $\begin{array}{l}\text { Energy } \\
\text { Recuperation } \\
\text { Processes } \\
\end{array}$ & $\begin{array}{l}\text { Fuel } \\
\text { Produced }\end{array}$ & $\begin{array}{l}\text { Powertrain } \\
\text { Technology }\end{array}$ \\
\hline \multirow{20}{*}{$\begin{array}{l}\text { Food \& } \\
\text { Drinks }\end{array}$} & \multirow{6}{*}{$\begin{array}{l}\text { Agricultural } \\
\text { Production, } \\
\text { Storage \& } \\
\text { Processing }\end{array}$} & $\begin{array}{l}\text { Product Losses } \\
\& \text { Waste }\end{array}$ & $\begin{array}{l}\text { Anaerobic } \\
\text { Digestion }\end{array}$ & Biomethane & ICE (Natural Gas) \\
\hline & & $\begin{array}{l}\text { Non-edible } \\
\text { parts }\end{array}$ & Biomass-to-Liquid & $\begin{array}{l}\text { Biodiesel } 2^{\text {nd }} \\
\text { generation }\end{array}$ & \multirow{3}{*}{ ICE (Diesel) } \\
\hline & & \multirow{3}{*}{$\begin{array}{l}\text { Oil seeds } \\
\text { Losses }\end{array}$} & Transesterification & $\begin{array}{l}\text { Biodiesel } 1^{\text {st }} \\
\text { generation }\end{array}$ & \\
\hline & & & $\begin{array}{l}\text { Hydrogenation } \\
\text { Vegetable Oil }\end{array}$ & $\begin{array}{l}\text { Biodiesel } 2^{\text {nd }} \\
\text { generation }\end{array}$ & \\
\hline & & & $\begin{array}{l}\text { Anaerobic } \\
\text { Digestion }\end{array}$ & Biomethane & \multirow{3}{*}{ ICE (Natural Gas) } \\
\hline & & Water effluent & & & \\
\hline & \multirow{4}{*}{$\begin{array}{l}\text { Animal } \\
\text { Production } \\
\& \text { Meat } \\
\text { Processing }\end{array}$} & $\begin{array}{l}\text { Product Losses } \\
\& \text { Waste }\end{array}$ & $\begin{array}{l}\text { Anaerobic } \\
\text { Digestion }\end{array}$ & Biomethane & \\
\hline & & \multirow{2}{*}{ Fat } & Trans esterification & $\begin{array}{l}\text { Biodiesel } 1^{\text {st }} \\
\text { gen. }\end{array}$ & \multirow{2}{*}{ ICE (Diesel) } \\
\hline & & & $\begin{array}{l}\text { Hydrogenation } \\
\text { Vegetable Oil } \\
\end{array}$ & $\begin{array}{l}\text { Biodiesel 2 } \\
\text { generation }\end{array}$ & \\
\hline & & Slurry, Manure & \multirow{6}{*}{$\begin{array}{l}\text { Anaerobic } \\
\text { Digestion }\end{array}$} & \multirow{6}{*}{ Biomethane } & \multirow{6}{*}{ ICE (Natural Gas) } \\
\hline & \multirow{2}{*}{ Dairy } & Milk & & & \\
\hline & & Water Effluent & & & \\
\hline & \multirow[t]{2}{*}{ Drinks } & Water Effluent & & & \\
\hline & & Fruit Pulp & & & \\
\hline & \multirow{6}{*}{$\begin{array}{l}\text { Quick } \\
\text { Service } \\
\text { Restaurants }\end{array}$} & $\begin{array}{l}\text { Food waste \& } \\
\text { leftovers }\end{array}$ & & & \\
\hline & & Coffee Grounds & \multirow{2}{*}{ Trans esterification } & \multirow{2}{*}{$\begin{array}{l}\text { Biodiesel } 1^{\text {st }} \\
\text { generation }\end{array}$} & \multirow{3}{*}{ ICE (Diesel) } \\
\hline & & \multirow{2}{*}{$\begin{array}{l}\text { Used Cooking } \\
\text { oil \& Grease } \\
\text { Tap Waste }\end{array}$} & & & \\
\hline & & & $\begin{array}{l}\text { Hydrogenation } \\
\text { Vegetable Oil }\end{array}$ & $\begin{array}{l}\text { Biodiesel } 2^{\text {nd }} \\
\text { generation }\end{array}$ & \\
\hline & & $\begin{array}{l}\text { Mixed Waste: } \\
\text { Paper \& Card }\end{array}$ & $\begin{array}{l}\text { Anaerobic } \\
\text { Digestion }\end{array}$ & Biomethane & ICE (Natural Gas) \\
\hline & & $\begin{array}{l}\text { Mixed Waste: } \\
\text { Plastic \& Film } \\
\end{array}$ & & $\begin{array}{l}\text { Synthetic } \\
\text { Diesel, }\end{array}$ & \\
\hline \multirow[t]{2}{*}{$\begin{array}{l}\text { Oil \& } \\
\text { Plastics }\end{array}$} & \multirow[t]{2}{*}{$\begin{array}{l}\text { Plastic } \\
\text { Packaging }\end{array}$} & $\begin{array}{l}\text { Thermoplastics } \\
\& \text { Film }\end{array}$ & Pyrolysis & $\begin{array}{l}\text { Methane, } \\
\text { DME, } \\
\text { Methanol, } \\
\text { Hydrogen }\end{array}$ & $\begin{array}{l}\text { ICE. (Diesel, DME, } \\
\text { Methanol, Hydrogen), } \\
\text { Electric (SOFC) }\end{array}$ \\
\hline & & Bioplastics & $\begin{array}{l}\text { Anaerobic } \\
\text { Digestion }\end{array}$ & Biomethane & ICE (Natural Gas) \\
\hline \multirow{2}{*}{$\begin{array}{l}\text { Paper \& } \\
\text { Wood }\end{array}$} & \multirow{2}{*}{$\begin{array}{l}\text { Paper \& } \\
\text { Card } \\
\text { packaging, }\end{array}$} & Black liquor & $\begin{array}{l}\text { Anaerobic } \\
\text { Digestion }\end{array}$ & \multirow{2}{*}{ Biomethane } & \multirow{2}{*}{ ICE (Natural Gas) } \\
\hline & & Pulp waste & & & \\
\hline
\end{tabular}




\begin{tabular}{|c|c|c|c|c|c|}
\hline & \multirow[t]{8}{*}{$\begin{array}{l}\text { Wood } \\
\text { Pallets }\end{array}$} & & \multirow{6}{*}{$\begin{array}{l}\text { Pyrolysis \& } \\
\text { Gasification } \\
\text { (Syngas) }\end{array}$} & $\begin{array}{l}\text { Synthetic } \\
\text { diesel }\end{array}$ & ICE Diesel \\
\hline & & & & $\begin{array}{l}\text { Bio Dimethyl } \\
\text { Ether } \\
\text { (BioDME) }\end{array}$ & $\begin{array}{l}\text { Adapted Diesel, } \\
\text { Adapted Petrol } \\
\text { (70\%LPG/30\%DME) }\end{array}$ \\
\hline & & & & \multirow{2}{*}{ Hydrogen } & ICE (Hydrogen) \\
\hline & & & & & Electric (PEMFC) \\
\hline & & & & Bio Methanol & $\begin{array}{l}\text { Electric (Direct } \\
\text { Alcohol Fuel Cell) } \\
\text { Adapted Diesel (5\% } \\
\text { additives) }\end{array}$ \\
\hline & & & & & ICE (Adapted \\
\hline & & \multirow[t]{2}{*}{ Wood residues } & \multirow{2}{*}{$\begin{array}{l}\text { Fermentation } \\
\text { (Enzyme } \\
\text { Hydrolysis) }\end{array}$} & Bio Ethanol & $\begin{array}{l}\text { Gasoline) } \\
\text { ICE (Diesel with } \\
\text { additives) }\end{array}$ \\
\hline & & & & $\begin{array}{l}\text { Biodiesel } 2^{\text {nd }} \\
\text { generation }\end{array}$ & ICE (Diesel) \\
\hline Water & $\begin{array}{l}\text { Water } \\
\text { Treatment }\end{array}$ & Sewage, sludge & $\begin{array}{l}\text { Anaerobic } \\
\text { Digestion }\end{array}$ & Biomethane & ICE (Natural Gas) \\
\hline
\end{tabular}

\subsubsection{WTT Emissions for Different Feedstocks and Pathways from QSRs}

The carbon intensity and GHG savings of different waste-to-fuel pathways are shown in Table 4. Pathways WOFA3a and TOFA3a are the only ones currently followed by the case study QSRs. All the other pathways represent potential alternatives to produce fuels from waste considering specific feedstocks and conversion processes. The TTW values (Table 1) were added to the WTT values calculated to give the total WTW carbon intensity for each pathway (Table 4). The WTW GHG savings of the diesel and biodiesel pathways were then compared to the carbon intensity of the COD1, biomethane-to-GMCG1 and bioethanol-to-COG1 pathways as shown in Table 1. Compared to standard mineral diesel fuel, FAME biodiesel can save almost $85 \%$ WTW GHG emissions, a percentage that increases very slightly in the case of second generation biodiesel. Biomethane can yield almost 62\% WTW GHG savings compared to fossil natural gas fuel and 70\% compared to mineral diesel. Bioethanol saves almost 59\% compared to gasoline and 59.4\% when compared to diesel.

Table 4 Average carbon intensity and GHG emission savings of different pathways for the food chain studied.

\begin{tabular}{|c|c|c|c|c|c|c|c|}
\hline \multirow{3}{*}{$\begin{array}{l}\text { Pathway } \\
\text { Code }\end{array}$} & \multirow{3}{*}{$\begin{array}{c}\text { Waste } \\
\text { Feedstock }\end{array}$} & \multirow[t]{3}{*}{ Fuel } & \multicolumn{4}{|c|}{ Chain Carbon Intensity } & \multirow{3}{*}{$\begin{array}{l}\text { WTW GHG } \\
\text { Savings vs Fossil } \\
\text { fuel pathway }\end{array}$} \\
\hline & & & WTT Fuel & WTT & TTW & WTW & \\
\hline & & & $\begin{array}{c}\left(\mathrm{kg} \mathrm{CO} \mathrm{CO}_{2} \mathrm{eq}\right. \\
\text { /t bi ofuel) }\end{array}$ & \multicolumn{3}{|c|}{$\left(\mathrm{g} \mathrm{CO}_{2} \mathrm{eq} . / \mathrm{MJ}\right)$} & \\
\hline WOFA3a & $\mathrm{UCO}$ & FAME & 499 & 13.4 & 0.2 & 13.6 & $84.7 \%$ vs COD1 \\
\hline TOFA3a & Burger Fat & Biodiesel & 493 & 13.3 & 0.1 & 13.4 & $84.9 \%$ vs COD1 \\
\hline WOHY1a & UCO & $\mathrm{HVO}$ & 666 & 15.1 & -4.9 & 10.2 & $88.5 \%$ vs COD 1 \\
\hline TOHY1a & Burger Fat & Biodiesel & 654 & 14.9 & -5.2 & 9.7 & $85.1 \%$ vs COD1 \\
\hline FFCG1 & $\begin{array}{l}\text { Food } \\
\text { Waste }\end{array}$ & Biomethane & 1,030 & 22.9 & 3.5 & 26.4 & $\begin{array}{l}61.9 \% \text { vs } \\
\text { CMCG1 }\end{array}$ \\
\hline WWET1 & $\begin{array}{l}\text { Wood } \\
\text { Waste }\end{array}$ & Bioethanol & 714 & 35.8 & 0.2 & 36 & $58.7 \%$ vs COG1 \\
\hline
\end{tabular}

As can be seen in Table 4, WTT GHG emissions from first generation biodiesel are lower than those from second generation but despite their greater efficiency in converting waste to fuel, there are no commercial second generation biofuel production plants in the UK so the feedstock has to be shipped overseas, and the end fuel brought back to Great Britain. These long distances increase the carbon intensity of the TTW chain. If all feedstocks were processed in the domestic market or otherwise sold in the countries where those facilities are located, the WTW GHG savings would increase considerably. Benefiting from these additional carbon savings could be possible by developing an offsetting mechanism similar to Green Certificates applicable to transportation at an EU level. In this way, a feedstock could be processed in one country, shipped to another and bought into the local market without the need for physically importing it. 
When considering the WTW emissions, with the exception of the WWET1 pathway, all others deliver the sustainability criteria as defined by the EU Directive 2009/28/EC which states that a biofuel must save at least $60 \%$ GHG emissions to benefit from European subsidies (DfT, 2013b, European Commission, 2013). The results in Table 4 differ from those reported in Table 1 , as they are specific to the supply chains studied. In Figures 3-6, the haulage distances are expressed in $\mathrm{km}$ while the percentages represent the contribution of each stage to the total TTW carbon intensity. The percentages shown represent the contribution of a particular stage to the overall GHG emissions for the waste-to-fuel pathway. Road and nautical distances have been converted into kilometres and quoted on top of the arrows representing the distance between origin and destination. The pathways from plastics to synthetic diesel have been excluded as no GHG emissions savings are expected.

\subsubsection{WTT Emissions of UCO and Burger Fat to Biodiesel}

Across all the case study restaurants, UCO and fat is collected in the QSRs, consolidated in a DC and converted into FAME biodiesel following the chain illustrated in Figure 3. As a potential alternative (not currently being undertaken) pathways WOHY1a and TOHY1a represent the same possibility for producing second generation biodiesel (HVO) from the same feedstocks (Figure 4).

In WOFA3a and WOHY1a pathways the oil is collected in an oil tank built into the HGVs. In TOFA3a and TOHY1a pathways, tallow is collected and transported in barrels from QSRs to the conversion plant. This reduces the carbon intensity as there is no energy consumption for transferring from/to and maintaining feedstock in storage tanks. Figure 3 shows the chain of UCO waste to FAME biodiesel production. Initially, the UCO is collected in small storage tanks located in the QSRs and pumped into larger $300 \mathrm{~L}$ oil tanks fitted in the delivery trailer's chassis. Once these arrive at the DC, the UCO is stored in a tank with a capacity of several thousand litres, awaiting collection from a third party processing organisation located at an average distance of $240 \mathrm{~km}$. The UCO is stored at the processing plant until it is refined and transesterified. The conversion process stages represent $86 \%$ of the total carbon emissions of the chain. The first generation biofuel is sent back to the DC where it is stored and made ready to be used by the logistics fleets. In this case the WTT carbon intensity calculated (13.4 $\left.\mathrm{g} \mathrm{CO}_{2} \mathrm{eq} . / \mathrm{MJ}\right)$ is very similar to the one reported by Edwards, Larive (2014) in Table 1.

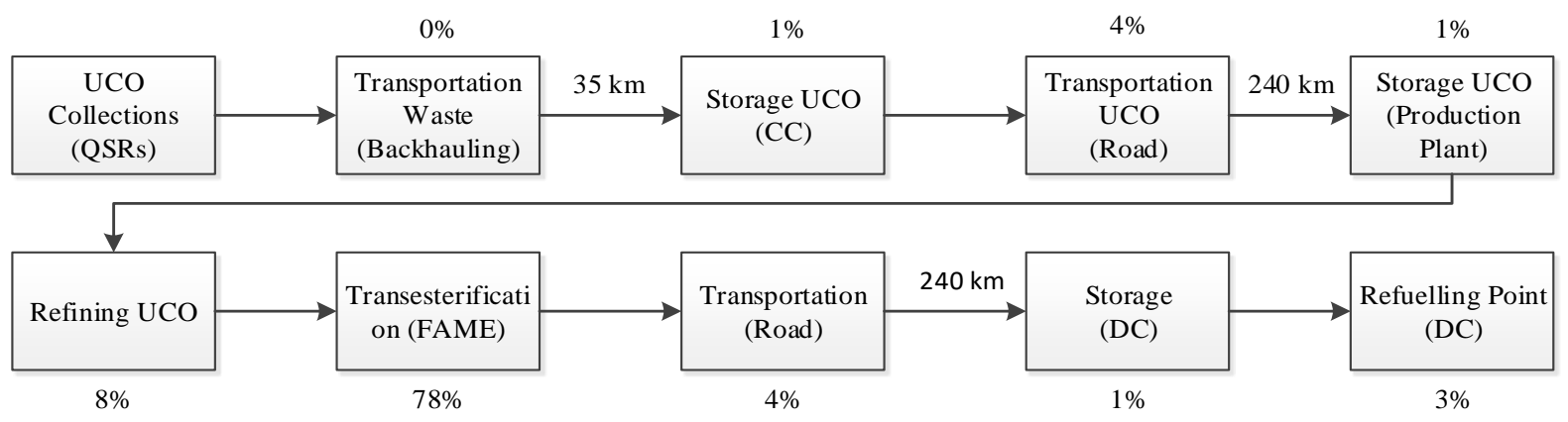

Figure 3. UCO to FAME biodiesel chain (WOFA3a pathway).

TOFA3 a pathway represents the conversion of tallow (burger fat) to FAME biodiesel. The stages are the same as the WOFA3a pathway with the only difference that fat is stored in barrels until it reaches the processing plant. There is thus no additional energy demand associated with its initial storage. This reduces the carbon intensity by $0.1 \mathrm{~g}$ to $13.3 \mathrm{~g} \mathrm{CO}_{2} \mathrm{eq} . / \mathrm{MJ}$, around half of the value reported in Table 1 . Refining and transesterification represent $87 \%$ of the total carbon emissions of this chain.

While first generation biofuels are produced in the UK, second generation biodiesel (e.g. HVO) is produced in the Netherlands, hence shipping waste overseas and bringing back the processed biofuel explains the increase in carbon emissions for the WOHY1 a and TOHY1a pathways. The conversion of UCO and tallow into second generation biofuel is feasible; however, the production plant company contacted for this study indicated that a chemical analysis should be undertaken before accepting these types of feedstocks. Figure 4 illustrates the chain for conversion of UCO into HVO biodiesel (WOHY1a). The WTT carbon intensity for this pathway is $15.1 \mathrm{~g}$ $\mathrm{CO}_{2}$ eq./MJ, a value very similar to the one reported in Table 1. In this chain, waste is consolidated in the DC and transported an average distance of $267 \mathrm{~km}$ by road to the port of Felixtowe where it is shipped to Rotterdam (134 nautical miles) by a ship tanker. Once in the Netherlands, after a short trip by road, it reaches the Neste Oil processing plant. After the hydrogenation process, a high quality biodiesel is produced and it is assumed that this is shipped back to the DC in the UK where it can be stored and supplied to the fleet.

The TOHY1a pathway (fat to HVO biodiesel) chain is similar to Figure 4; however, tallow is transported in barrels all the way through. This means that the lorry carries dry product and that the ship is an ocean bulk carrier. On the way back, the liquid fuel is transported by sea tankers and trucks for liquids. This makes that the 

respectively.

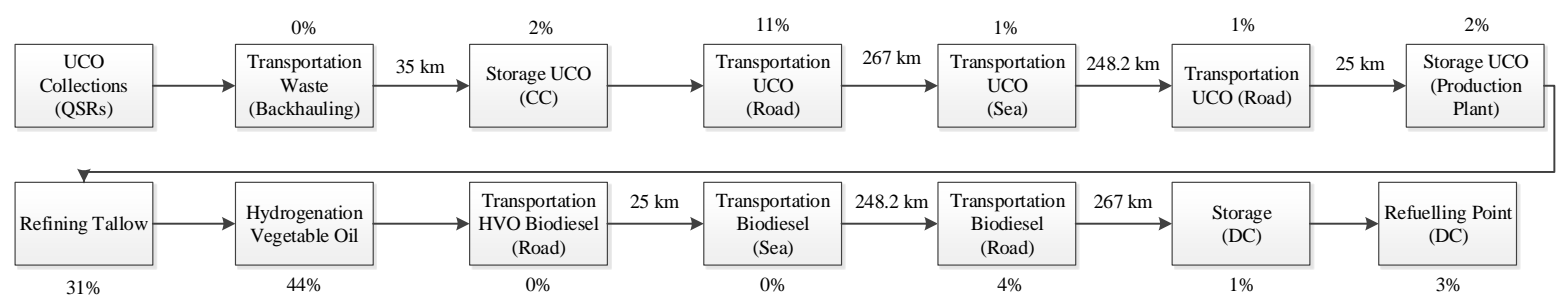

Figure 4 UCO TO HVO biodiesel chain (WOHY1a pathway).

\subsubsection{WTT Emissions of Food Waste to Biomethane}

The FFCG1 pathway is represented in Figure 5. Food waste is collected in QSRs and stored in the DC where it is shipped to the closest $\mathrm{AD}$ plant. After the digestion of the waste, the biogas is upgraded to $95 \%$ biomethane and is injected into the UK natural gas grid. The biomethane can be consumed in the DC by natural gas HGVs engines as CNG. Refuelling represents a substantial percentage of the energy intensity of the chain $(13 \%)$ as the gas has to be pressurised from 85 bar (national grid) to 250 bars (vehicle gas tank pressure). This is necessary as a higher pressure means lower fuel tank volume (at the same temperature) which minimises the impact on vehicle volumetric payload. Using LNG instead of CNG would increase vehicle range (for the same gas tank volume); however, this would add an additional step where the gas would have to be pressurised and kept at cryogenic temperature, increasing the carbon intensity of the chain even further and therefore reducing the GHG savings.

Consolidating food waste in the DCs and shipping such waste to the nearest $\mathrm{AD}$ plant generates $26.4 \mathrm{~g}$ $\mathrm{CO}_{2}$ eq./MJ of output energy (as shown in Table 4). This represents $70.2 \%$ lower carbon emissions than those reported in Table 1 for mineral diesel $\left(88.6 \mathrm{~g} \mathrm{CO}_{2}\right.$ eq./MJ) and almost $62 \%$ lower than those for fossil natural gas. This result is slightly lower than the savings of $83 \%$ reported in Table 1 for the OWCG1 pathway; there, however, the organic fraction included all municipal wastes whilst in the FFCG1 pathway only fast food waste was considered, with the yields reported in Table 2. The energy required for the pasteurisation of the digestate to meet PAS110 regulations has not been included in this chain, as it does not directly relate to the production of the fuel and it could be attributed to the buyer of the fertilizer (digestate).

Additional modelling has shown that if the food waste would be shipped to an $\mathrm{AD}$ plant $100 \mathrm{~km}, 200 \mathrm{~km}$, $300 \mathrm{~km}$ and $400 \mathrm{~km}$ far away (instead of the closest one to the DC), the total GHG savings would decrease to $55.3 \%, 38.5,21.8 \%$ or $5 \%$ respectively. This means that the carbon intensity of the FFCG1 pathway is highly sensitive to the distance between feedstock production and $\mathrm{AD}$ plant location.

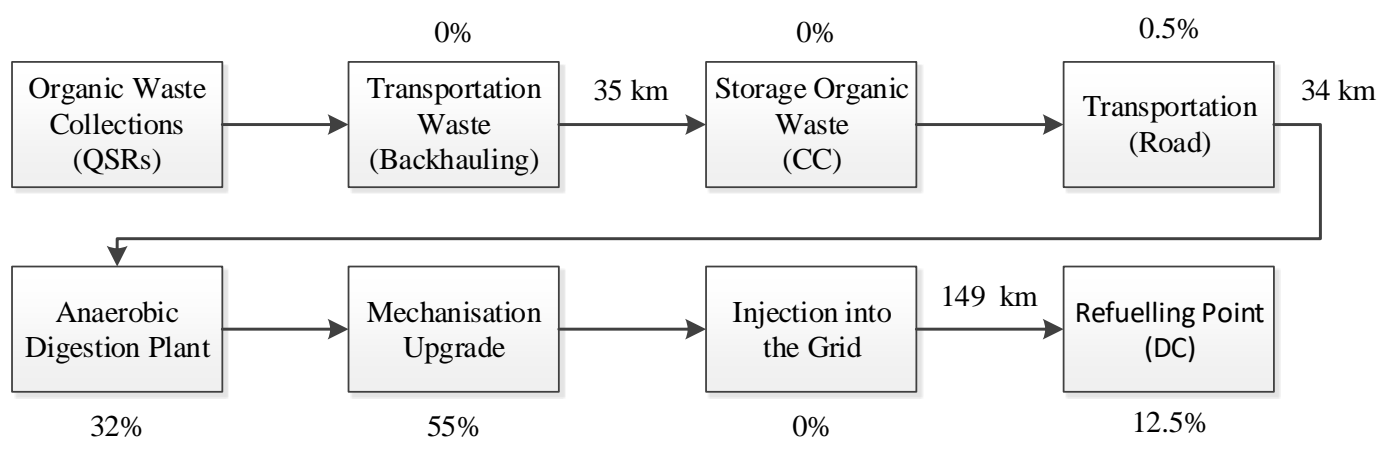

Figure 5. Restaurant food waste to biomethane chain (FFCG1 pathway).

\subsubsection{WTT Emissions of Wooden Pallets to Bioethanol}

Wood waste is mainly generated through wear-and-tear on wooden pallets. Wood waste could be converted into liquid or gas biofuels through BTL or biomass-to-gas processes, such as Fischer-Tropsch biodiesel (FTDiesel) and bioDME respectively. Both pathways are very promising with GHG savings of $98 \%$ reported from wood waste to BioDME (BioDME, 2012, Edwards, Larive, 2014) and 97\% for wood waste to FT Diesel (Edwards, Larive, 2014). Producing lingo-cellulosic ethanol from paper and cardboard waste also seems feasible; this was excluded from the current assessment, however, as no such processing plants were found to operate in Europe. 
(bioethanol) and for this reason, all the other pathways for this feedstock were excluded. Bioethanol can be used in adapted petrol engines; it is also possible to adapt diesel engines to run on $95 \%$ ethanol plus a $5 \%$ of ignition enhancing additives (ignition improver, lubricant and corrosion) as developed by Sekab and used in Scania engines (Sekab, 2013).

A carbon intensity of $35.8 \mathrm{~g} \mathrm{CO}_{2}$ eq./MJ was estimated and WTT GHG savings around $57 \%$ for pathway WWET1 are suggested. This differs from the $72 \%$ GHG savings reported by Edwards, Larive (2014). The reason is that in the current case, the shipping of wood chips to the locations of the processing plants (Norway) and bringing the output back represents a high percentage of the overall emissions of the chain. This performance is below the $60 \%$ required to meet the EU sustainability criteria previously mentioned.

Figure 6 represents the WWET1 pathway where wasted wood (e.g. wooden pallets) is converted into bioethanol. In this pathway, it is assumed that wasted wood is stored in the DC, collected by a third party that crushes the wood into pellets and ships them from the Port of Felixstowe to the Port of Havneholmen (Norway) by bulk carrier. There, after an $18 \mathrm{~km}$ trip, they reach their destination in the Borregaard Synthesis plant where they could be processed and converted into bioethanol.

Despite the fact that using wood pallets from the logistics industry to produce fuels is technically feasible, it is always better to reuse pallets as emissions from procuring reused pallets are just under $7 \%$ of the emissions of making pallets from primary wood, as stated in Defra (2013b) emission factors. Also, this pathway has economic implications as removing usable pallets would impact market prices of second hand ones.

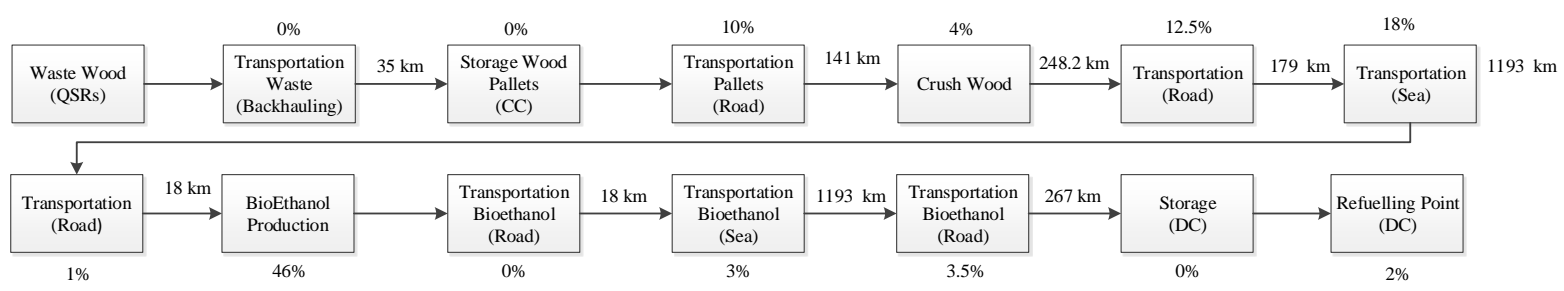

Figure 6. Wood Waste (pallets) to Bioethanol for the QSRs network of the case study (WWET1 pathway).

\subsection{Quantifying the Potential Transportation Fuel Generation from QSR Waste Arising Across the UK}

\subsubsection{Main Waste Fractions}

Based on the case study data obtained from a QSR chain over 3 years, the potential implications for fuel production from QSR waste arising nationally were estimated (Table 5). The results suggested that British QSRs and their DCs generate around 24.9 tonnes of waste per outlet each year that can be used to produce fuels. Cardboard and paper fractions represented over half the tonnage generated, with food waste making up the second largest fraction with a quarter, and fats and UCO the third with $17 \%$ of the total. Plastic represented just $2 \%$ of the total tonnage produced.

In Table 5, each pathway represents the fuel produced by a specific feedstock and conversion process, considering the energy yields shown in Table 2 and LHV from Table 6 . The total fuel availability has been converted into GJ to allow an easy comparison of the effectiveness of each pathway and contrast this with the demand of diesel from British HGVs.

When QSRs and DCs separated waste collections and QSRs mixed food waste are consolidated, cardboard and paper represent over $50 \%$ of all weight, food waste a quarter, UCO and fat $17 \%$, wood pallets $4 \%$ and plastics just $2 \%$. Based on the energy content of each feedstock (Table 6), an average restaurant has the potential to produce $537 \mathrm{GJ}$ of energy per year. From this, cardboard and paper represent around $40 \%$ of the total energy, while UCO and fats rises represent $29 \%$, followed by food waste with $23 \%$, wood pallets with $4 \%$ and plastics with a mere $3 \%$. However these yields are much lower when waste is finally converted into liquid or gas fuels.

\subsubsection{Energy Yields Scenarios}

Three scenarios were created showing the kilometres that could be run with waste made from fuel from British QSRs. These scenarios show the energy content available from each fuel, the distance that could be run with the vehicles using them and how many HGVs could be powered per year (Table 7).

The fuel equivalence of the feedstocks shown in Table 5 is calculated according to three different scenarios as shown in Table 8. The scenarios represent the outcomes of pathways FFCG1, CACG1, PACG1, WWET1 and PFSD and PBSD in combination with another two pathways more (TOFA3A and WOFA3a or TOHY1a and 
WOHY1a) depending on the final use of UCO and fat. In addition to the conversion of paper and cardboard to biomethane, wood to bioethanol and plastics into synthetic diesel in all three scenarios, the only differences are:

- Scenario 1 represents the use of UCO and fat to produce FAME biodiesel (WOFA3a, and TOFA3a pathways).

- Scenario 2, represents the use of UCO and fat to produce HVO biodiesel (WOHY1a and TOHY1 a pathways) in addition to paper and cardboard to biomethane, wood to bioethanol and plastics to synthetic diesel.

- Scenario 3, represents the use of UCO and fat to produce biomethane (WOCG1 and TACG1 pathways) in addition to paper and cardboard to biomethane, wood to bioethanol and plastics to synthetic diesel.

Table 5 Waste-to-fuel potential from British QSRs (assuming 3 DCs for each 1,000 outlets).

\begin{tabular}{|c|c|c|c|c|c|c|c|c|}
\hline $\begin{array}{l}\text { Pathway } \\
\text { Code }\end{array}$ & Feedstock & $\begin{array}{c}\text { Waste } \\
\text { generation } \\
\text { per year }\end{array}$ & Unit & $\begin{array}{c}\text { Total GJ } \\
\text { (LHV) }\end{array}$ & $\begin{array}{c}\text { Resul ting } \\
\text { Fuel }\end{array}$ & $\begin{array}{c}\mathrm{U} \\
\text { nit }\end{array}$ & $\begin{array}{c}\text { Final } \\
\text { Total GJ } \\
\text { (LHV) }\end{array}$ & Fuel \\
\hline WOFA3a & \multirow{3}{*}{ UCO } & \multirow{3}{*}{120,629} & \multirow{3}{*}{$\mathrm{m}^{3}$} & \multirow{3}{*}{$4,101,387$} & $113,362,870$ & $\mathrm{~L}$ & $3,753,218$ & FAME \\
\hline WOHY1a & & & & & $45,580,232$ & $\mathrm{~L}$ & $1,564,314$ & HVO \\
\hline WOCG1 & & & & & $52,271,583$ & $\mathrm{~kg}$ & $2,571,762$ & Biomethane \\
\hline TOFA3 & \multirow{3}{*}{$\begin{array}{l}\text { Fat } \\
\text { (Tallow) }\end{array}$} & \multirow{3}{*}{60,612} & \multirow{3}{*}{$\mathrm{m}^{3}$} & \multirow{3}{*}{$2,063,241$} & $56,961,247$ & $\mathrm{~L}$ & $1,885,873$ & FAME \\
\hline TOHY1a & & & & & $22,902,621$ & $\mathrm{~L}$ & 786,018 & $\mathrm{HVO}$ \\
\hline TACG1 & & & & & $40,500,868$ & $\mathrm{~kg}$ & $1,992,643$ & Biomethane \\
\hline FFCG1 & Food Waste & 242,586 & ton & $5,021,524$ & $122,099,674$ & $\mathrm{~kg}$ & $6,007,304$ & Biomethane \\
\hline CACG1 & Cardboard & 508,224 & ton & $8,731,290$ & $98,555,880$ & $\mathrm{~kg}$ & $4,848,949$ & Biomethane \\
\hline PACG1 & Paper & 543 & ton & 7,144 & 54,019 & $\mathrm{~kg}$ & 2,658 & Biomethane \\
\hline WWET1 & Pallets & 42,182 & ton & 780,364 & $8,642,498$ & $\mathrm{~L}$ & 183,905 & Bioethanol \\
\hline PFSD & $\begin{array}{l}\text { Plastics } \\
\text { (Film PP) }\end{array}$ & 9,190 & ton & 404,366 & $8,638,136$ & $\mathrm{~L}$ & 296,461 & $\begin{array}{l}\text { Synthetic } \\
\text { Diesel }\end{array}$ \\
\hline PBSD & $\begin{array}{l}\text { Plastics } \\
\text { (HDPE) }\end{array}$ & 6,135 & ton & 269,951 & $5,766,745$ & $\mathrm{~L}$ & 197,915 & $\begin{array}{l}\text { Synthetic } \\
\text { Diesel }\end{array}$ \\
\hline
\end{tabular}

Table 6 Energy content of different feedstocks.

\begin{tabular}{|l|l|l|l|}
\hline \multicolumn{1}{|c|}{ Product } & LHV & \multicolumn{1}{c|}{ Unit } & \multicolumn{1}{c|}{ Source } \\
\hline Typical Diesel & 43.10 & $\mathrm{GJ} /$ tonne & Edwards, Larive (2014) \\
\hline FAME & 33.11 & $\mathrm{GJ} / \mathrm{m}^{3}$ & Edwards, Larive (2014) \\
\hline HVO & 34.32 & $\mathrm{GJ} / \mathrm{m}^{3}$ & Edwards, Larive (2014) \\
\hline Biomethane & 49.20 & $\mathrm{GJ} / \mathrm{tonne}^{2}$ & Edwards, Larive (2014) \\
\hline Bioethanol & 21.28 & $\mathrm{GJ} / \mathrm{m}^{3}$ & Edwards, Larive (2014) \\
\hline Synthetic Diesel & 34.32 & $\mathrm{GJ} / \mathrm{m}^{3}$ & Edwards, Larive (2014) \\
\hline UCO (refined oil) & 34.00 & $\mathrm{GJ} / \mathrm{m}^{3}$ & Edwards, Larive (2014) \\
\hline Fat (Tallow) & 34.04 & $\mathrm{GJ} / \mathrm{m}^{3}$ & Edwards, Larive (2014) \\
\hline Food Waste & 20.70 & $\mathrm{GJ} /$ tonne & Banks and Zhang (2010) \\
\hline Cardboard & 17.18 & $\mathrm{GJ} /$ tonne & Banks and Zhang (2010) \\
\hline Paper & 13.16 & $\mathrm{GJ} /$ tonne & Banks and Zhang (2010) \\
\hline Pallets (Wood Logs) & 18.50 & $\mathrm{GJ} /$ tonne & Edwards, Larive (2014) \\
\hline Plastics (Film PP) & 44.00 & $\mathrm{GJ} /$ tonne & Themelis and Mussche (2014) \\
\hline Plastics (Bottles HDPE Natural) & 44.00 & $\mathrm{GJ} /$ tonne & Themelis and Mussche (2014) \\
\hline
\end{tabular}


feedstocks of the FFSC would be enough to run between 910 and 1,221 million km per year. This means that between 6,659 and 8,928 HGVs could be powered with fuels from waste streams (Table 8). Excluding PFSD and PBSD pathways from these values due to their lack of GHG savings, British fast food fleets could run between 864 and 1,174 million km per year with very low carbon fuels, this is between 6,317 and 8,587 HGVs depending on the scenario chosen, these numbers are considerably superior to the number of HGVs distributing to QSRs in Great Britain.

In Scenario 1, the conversion of UCO and burger fat into FAME biodiesel yields 5.6 million GJ, more than double compared to when the same feedstocks are converted into HVO biodiesel in the second scenario. In this scenario, the conversion of feedstocks into FAME biodiesel (B100), biomethane and bioethanol, yields the largest energy production of all three scenarios with over 17 million GJ, enough to drive almost $1.2 \mathrm{million} \mathrm{km}$ with renewable fuels. Under scenario 2, UCO and fat are converted into second generation biodiesel (HVO). Under this scenario, 6,659 vehicles could run with a mix of different fuels. As the conversion efficiency is lower, scenario 2 presents the lowest energy yield of all three scenarios with 3.3 million GJ/year less energy than scenario 1 and $2.2 \mathrm{GJ} /$ year than scenario 3 .

Scenario 3 was developed after interviews conducted with truck manufacturers who indicated that new sales of HGVs from January 2014 had to meet the Euro 6 emission standard and that these vehicles would see their warranty made void if vehicles use biodiesel in concentrations exceeding the EN590 standard (DAF Trucks Ltd., 2013, Mercedes-Benz, 2013, Volvo Trucks, 2013). This means that concentrations beyond 7\% of FAME biodiesel or $30 \%$ of HVO biodiesel are not allowed in Euro 6 trucks. If the FFSC wants to convert all waste streams into transportation fuels and consume all of it, scenario 3 represent the only alternative. In the other scenarios, the production of fuel exceeds the potential demand of Euro 6 vehicles owned by the FFSC. In this scenario, UCO and fat are co-digested to produce biomethane. This approach would yield 15.4 million GJ of biomethane; enough to run 898 million $\mathrm{km} /$ year and power 6,566 biomethane vehicles in addition to the yields of bioethanol and synthetic diesel common to all three scenarios.

Ethanol is a fuel that is found in concentrations of up to $10 \%$ in European conventional petrol following the EN228 fuel standard. It is also possible to use pure ethanol in some engines. It is estimated that such alternative would produce enough power trucks for almost 9.9 million $\mathrm{km}$ or 73 trucks per year. As bioethanol has a lower energy intensity than biodiesel, long haul routes may require larger fuel tanks which could potentially impact on the vehicle payload. As previously mentioned, bioethanol can also be used in diesel engines with the addition of certain additives.

The use of plastics common to all three scenarios could power $341 \mathrm{HGVs}$ each year. However, this would not lead to GHG savings as plastics are made from fossil hydrocarbons. Furthermore, it is difficult to guarantee that only end of life plastics are used. As procuring virgin plastic is more expensive and carbon intensive than recycling it, the GHG emissions of pathways PFSD and PBSD are likely to increase carbon emissions and plastic prices if not managed well.

\subsubsection{WTW GHG Emissions}

Since October 2013, the Companies Act 2006 Regulations 2013 oblige all UK quoted companies to report on their GHG emissions (Defra, 2013b). Based on the UK Government methodology for company reporting (Hill, Venfield, 2013), assuming that the fleets are owned or controlled by the logistics operators, and using the emission factors reported in Table 4, the carbon emissions and savings for each scenario have been calculated as appear in Table 8 .

Scenario 1 produced the most energy and therefore could displace more conventional diesel, producing higher GHG savings. Scenario 1 indicates that replacing 17.1 million GJ of conventional diesel for biodiesel, biomethane and bioethanol would reduce GHG emissions by almost 900 thousand tonnes of $\mathrm{CO}_{2}$ eq. per year (almost 32\% less). Similarly, scenario 2 shows savings of almost 652 thousand tonnes per year (36\% less). Scenario 3 shows that 671 thousand tonnes per year (over $40 \%$ less than using conventional natural gas) could be saved by using most of the waste feedstocks to produce biomethane. This suggests that Scenario 1 will yield the highest carbon savings overall. Looking at the carbon intensity of each scenario normalising to tonnes of $\mathrm{CO}_{2}$ eq./GJ, Scenario 1 carbon intensity is the lowest of all three scenarios with $24.1 \mathrm{~kg} \mathrm{CO}$ eq./GJ (Table 9).

Detailed data regarding the fuel consumption of QSR distribution fleets in British districts is unavailable. Extrapolating the number of vehicles of the case study and in addition considering that Euro 6 diesel vehicles can only use low percentages of biofuels, it is evident that the fuel potential production from wastes from the British FFSC exceeds its demand. 
Table 7 Potential energy produced from wastes, $\mathrm{km}$ replaced with alternative fuels and number of vehicles powered by these (assuming $\left.136,000 \mathrm{~km} \mathrm{year}^{-1}\right)$. Quantities are in litres, except biomethane that is in $\mathrm{kg}$.

\begin{tabular}{|c|c|c|c|c|c|c|c|c|c|c|c|c|}
\hline \multirow[b]{2}{*}{ Fuel } & \multicolumn{4}{|c|}{ Scenario 1 - UCO/Fat to FAME B100 } & \multicolumn{4}{|c|}{ Scenario 2 - UCO/Fat to HVO B100 } & \multicolumn{4}{|c|}{ Scenario 3 - UCO/Fat to Biomethane } \\
\hline & $\begin{array}{c}\text { Potential } \\
\text { Production }\end{array}$ & GJ & $\begin{array}{c}\text { Million } \\
\text { km }\end{array}$ & Vehicles & $\begin{array}{c}\text { Potential } \\
\text { Production }\end{array}$ & GJ & $\begin{array}{c}\text { Million } \\
\text { km }\end{array}$ & Vehicles & $\begin{array}{c}\text { Potential } \\
\text { Production }\end{array}$ & GJ & $\begin{array}{c}\text { Million } \\
\text { km }\end{array}$ & Vehicles \\
\hline $\begin{array}{l}\text { Biodiesel } \\
\text { (L) }\end{array}$ & $170,324,117$ & $5,639,091$ & 532.3 & 3,891 & $68,482,853$ & $2,350,332$ & 221.8 & 1,622 & - & - & - & - \\
\hline $\begin{array}{l}\text { Biomethane } \\
\text { (kg) }\end{array}$ & $220,709,573$ & $10,858,911$ & 632.4 & 4,623 & $220,709,573$ & $10,858,911$ & 632.4 & 4,623 & $313,482,024$ & $15,423,316$ & 898.2 & 6,566 \\
\hline $\begin{array}{l}\text { Bioethanol } \\
\text { (L) }\end{array}$ & $8,642,498$ & 183,905 & 9.9 & 73 & $8,642,498$ & 183,905 & 9.9 & 73 & $8,642,498$ & 183,905 & 9.9 & 73 \\
\hline $\begin{array}{l}\text { Synthetic } \\
\text { Diesel (L) }\end{array}$ & $14,404,880$ & 494,375 & 46.7 & 341 & $14,404,880$ & 494,375 & 46.7 & 341 & $14,404,880$ & 494,375 & 46.7 & 341 \\
\hline & Total & $1717,176,283$ & $1,221.3$ & 8,928 & & ב13,887,523 & 910.8 & 6,659 & & "16,101,597 & 954.8 & $6,9,980$ \\
\hline
\end{tabular}

Table 8 GHG Savings for each scenario

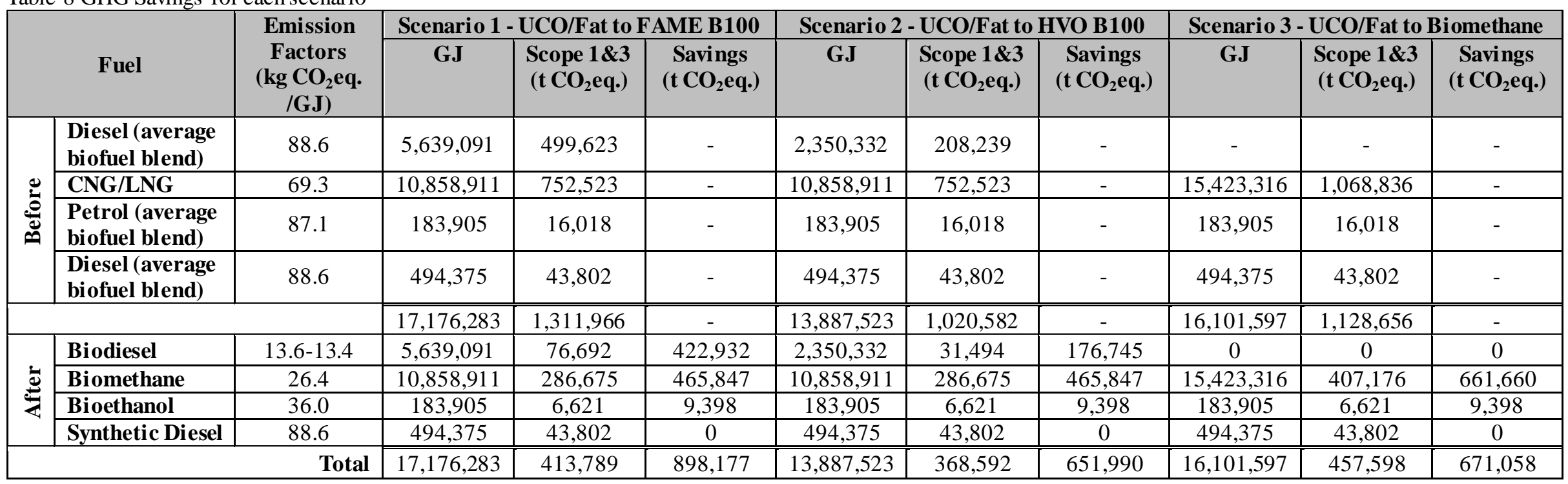


Table 9 Carbon intensity of each scenario (in $\mathrm{kg} \mathrm{CO}_{2}$ eq./GJ)

\begin{tabular}{|l|r|r|r|}
\hline \multicolumn{1}{|c|}{ Carbon Intensity } & $\begin{array}{c}\text { Scenario 1 - UCO/Fat } \\
\text { to FAME B100 }\end{array}$ & $\begin{array}{c}\text { Scenario 2 - UCO/Fat to } \\
\text { HVO B100 }\end{array}$ & $\begin{array}{c}\text { Scenario 3 - UCO/Fat to } \\
\text { Biomethane }\end{array}$ \\
\hline Before & 76.4 & 73.5 & 70.1 \\
\hline After & 24.1 & 26.5 & 28.4 \\
\hline Savings & $68.5 \%$ & $63.9 \%$ & $59.5 \%$ \\
\hline
\end{tabular}

497

The percentage of fuel consumption from HGVs that could be powered by wastes produced by QSRs according to scenario 1 is shown in Figure 7; this includes the fuel consumption from all British HGVs as reported by DECC (2013), not just QSR distribution fleets. The fuel consumption of HGVs (excluding buses) in the UK was around 7 million tonnes in 2011, a quantity that decreased to almost 6.9 in 2012 (DECC, 2013). Assuming that all HGVs consumed a standard average diesel blend and that the fuel density was $43.1 \mathrm{GJ} / \mathrm{t}$ this translates to a demand of 303.27 and 296.6.5 million GJ in 2011 and 2012 respectively. This indicates that in 2011 around $5.7 \%, 4.6 \%$ and $5.3 \%$ of the energy could be supplied by wastes from the FFSC for scenarios 1,2 and 3 respectively and $5.8 \%, 4.7 \%$ and $5.4 \%$ in 2012 . If we exclude non-biogenic feedstock, the percentages were slightly lower at 5.5\%, 4.4\% and 5.1\% in 2011 and 5.6\%, 4.5\% and 5.2\% in 2012 .

Based on scenario 1, Table 10 shows the British districts where fuel from waste can provide over $20 \%$ of the energy needs of the area. Greater London presents the highest waste-to-fuel energy output due to the concentration of 7,313 QSRs. Under scenario 1, London could produce 3.1 million GJ of fuels, representing $24 \%$ of the energy needs of the area (13.1 million GJ). This percentage decreases to $19.4 \%$ under scenario 2 and $22.5 \%$ in scenario 3. Blackpool's waste-to-fuel potential shows that over two thirds of all its diesel consumption in the district could be covered by fuels from waste streams. At the opposite extreme are the Isles of Scilly where no QSRs are found and therefore no fuels can be produced.

Table 10 Top 20 districts with the highest percentages of energy demand from HGVs' fleets that could potentially be covered by fuels produced by British QSRs waste each year.

\begin{tabular}{|c|l|c|c|c|c|}
\hline Ranking & \multicolumn{1}{|c|}{ District } & $\begin{array}{c}\text { Num. } \\
\text { Outlets }\end{array}$ & $\begin{array}{c}\text { Annual Fuel Potential } \\
\text { (in GJ averaged over } \\
\text { a 40 months peri od) }\end{array}$ & $\begin{array}{c}\text { Fuel Demand } \\
\text { in 2012 } \\
\text { (GJ) }\end{array}$ & \% \\
\hline 1 & Blackpool & 187 & 80,780 & 119,464 & 67.6 \\
\hline 2 & Southend-On-Sea & 144 & 62,205 & 156,288 & 39.8 \\
\hline 3 & Reading & 139 & 60,045 & 161,560 & 37.2 \\
\hline 4 & Bournemouth & 144 & 62,205 & 170,931 & 36.4 \\
\hline 5 & The City of Brighton and Hove & 259 & 111,883 & 330,582 & 33.8 \\
\hline 6 & Torbay & 104 & 44,926 & 149,302 & 30.1 \\
\hline 7 & Manchester District & 583 & 251,844 & 885,212 & 28.5 \\
\hline 8 & City Of Leicester & 294 & 127,002 & 480,631 & 26.4 \\
\hline 9 & Isle Of Wight & 76 & 32,830 & 125,218 & 26.2 \\
\hline 10 & Liverpool District & 390 & 168,472 & 658,621 & 25.6 \\
\hline 11 & Newcastle Upon Tyne District & 266 & 114,907 & 466,053 & 24.7 \\
\hline 12 & Greater London Authority & 7,313 & $3,159,070$ & $13,173,082$ & 24.0 \\
\hline 13 & City of Southampton & 192 & 82,940 & 354,605 & 23.4 \\
\hline 14 & Bradford District & 416 & 179,704 & 776,637 & 23.1 \\
\hline 15 & City of Wolverhampton District & 167 & 72,141 & 322,485 & 22.4 \\
\hline 16 & City of Nottingham & 275 & 118,795 & 549,733 & 21.6 \\
\hline 17 & City of Portsmouth & 176 & 76,028 & 365,925 & 20.8 \\
\hline 18 & Poole & 107 & 46,222 & 224,029 & 20.6 \\
\hline 19 & South Tyneside District & 121 & 52,270 & 253,625 & 20.6 \\
\hline 20 & Sheffield District & 531 & 229,381 & $1,123,263$ & 20.4 \\
\hline & & & & & \\
\hline
\end{tabular}




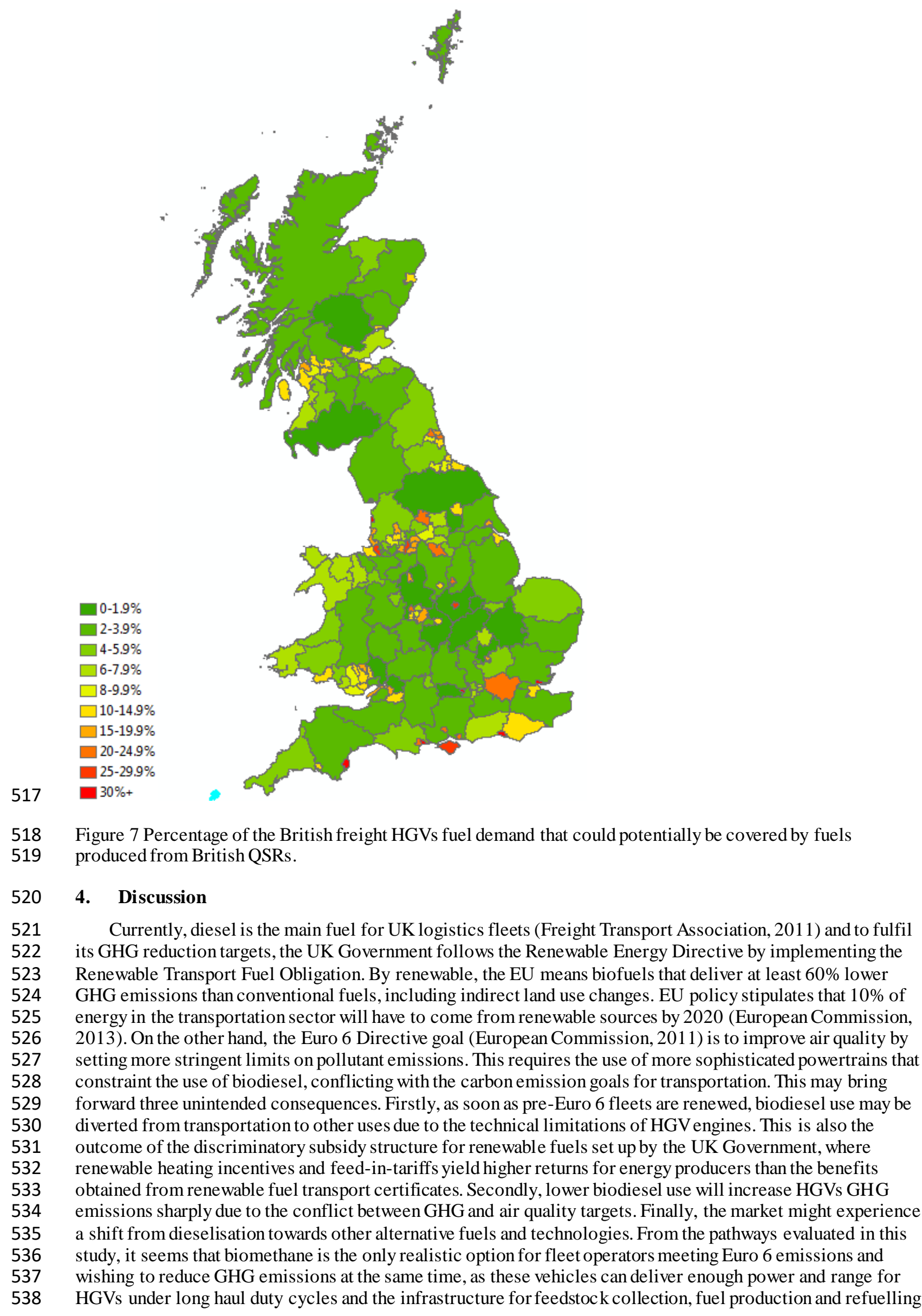


is well established. In the long run, reducing GHG emissions for specific vehicle classes and duty cycles may also be possible by developing more advanced biofuels and powertrain technologies such as BioDME, dual fuel trucks, hybrid and electric powertrains; however, this will require the deployment of second and third generation waste-to-fuel processing facilities, new refuelling infrastructure, some technology breakthroughs and affordable solutions that might require Governmental support either through subsidisation or favourable policies.

Waste management is an area that can give 3PL companies a source of competitive advantage, as their position in their respective supply chains allows them to manage waste collections at a reduced economic and environmental cost. Waste can be consolidated at DCs and used in-situ for producing heat and power or shipped to waste treatment plants where power, heat and fuels can be produced. The economics of conversion of QSR waste into fuel for transportation depends greatly on the density of QSRs, the possibility of guaranteeing a longterm supply of feedstock, the impact of waste reduction initiatives (e.g. efficiency improvements in the supply chain), feedstock and fuel market prices, operational and logistical complexities and Governmental policy and legislation in regards to renewable fuels incentives, carbon quotas and waste treatment.

Waste-to-fuel strategies present opportunities to reduce GHG emissions for the whole fast food supply chain while hedging against fuel price volatility and enhancing energy security. In this context, the role of policy makers is critical to establish a level playing field where some biofuels such as biomethane for transportation can compete with other uses. This is paramount when considering that the implementation of Euro 6 emission standards will make it more difficult to reduce GHG emissions for logistics fleets through the use of low carbon fuels, as the options are rather limited. Engine's manufacturers should also consider the potential for fuel production by British QSRs and realise that biodiesel can still play a huge role in the decarbonisation of the logistics sector and that more research and development should be carried out to overcome the technical challenges that Euro 6 brings and developing engines that can tolerate higher concentrations of biodiesel. At the same time, diesel and biodiesel as a fuel for transport seems to present challenges to many British and European local authorities trying to meet EU limits on air quality pollutants. This research suggests that biomethane is a recommendable fuel for road freight as it supports air quality and GHG targets.

Alternatively, the feedstocks and fuels presented here can be sold or transferred to other elements of the supply chain (e.g. farms, factories) for heating, cooling and/or power generation where it is possible to take advantage of more favourable governmental incentives (e.g. feed-in-tariffs, renewable heating incentives) than renewable transport fuel certificates. This could also reduce the carbon emissions of the supply chain as a whole; however, the emissions from these other links of the supply chain can be reduced more easily as those depend mainly on the percentage of renewable sources of the British mix grid.

\section{Conclusion}

The aim of this study was to quantify the waste-to-fuel potential from British QSRs and the WTW emissions of the most feasible pathways based on the waste streams of a major fast food chain. The results indicated that waste from British QSRs could cover the energy needs of between 4.4\%- 5.8\% of all British HGVs depending on the scenario and year. This translates to around 14-17 million GJ per year. Excluding non-biogenic feedstocks, thousands of vehicles could be powered with renewable fuels obtained from waste streams even if Euro 6 trucks cannot accept high concentrations of biodiesel, by using biomethane instead. As Euro 6 engines can only cope with up to $7 \%$ of FAME biodiesel or up to $30 \%$ of second generation HVO biodiesel, the surplus generated by the FFSC could be consumed by other national fleets. There is also an opportunity to produce synthetic diesel from plastics; however, carbon savings are unlikely. Risks were also found in the paper, cardboard and pallets waste-to-fuel pathways: Using feedstocks that have not reached their end of life could trigger economic and environmental drawbacks, as the costs and GHG emissions of virgin materials when producing new plastics, paper or pallets are higher than the recycled ones.

The reverse logistics of waste collections from QSRs managed by 3PLs show lower carbon emissions than those from dedicated waste fleets. Waste-to-fuel opportunities can become strategically important for 3PLs as solution to mitigate the volatility of freight energy costs. For 3PLs, waste consolidation can be placed at the DCs and when processing plants are located nearby, carbon emissions and transportation costs become minimal. On the other hand, dedicated waste collection fleets have the flexibility to place DCs in the optimal location to minimise their costs identifying the areas with higher densities of QSRs and the location of processing plants. In both cases, the high capital expenditure of second generation biofuels processing facilities and the uncertainties surrounding British energy policy has resulted in a lack of such facilities in the country, which leads to increased fuel costs and TTW emissions. Since the arrival of Euro 6 HGVs and once older Euro 5 fleets are renewed, diesel fleets will struggle to deliver GHG reduction targets. This may lay the foundations towards a considerable increase on the market share of biomethane HGVs as an alternative to reconcile the air quality and carbon emission agendas. 


$\begin{array}{llll}\text { 3PL } & \text { Third Party Logistics Provider } & \text { FT } & \text { Fischer-Tropsch } \\ \text { AD } & \text { Anaerobic Digestion } & \text { GHG } & \text { Greenhouse Gases } \\ \text { B100 } & \text { Diesel fuel 100\% Biologic Origin } & \text { GTW } & \text { Grease Trap Waste } \\ \text { BTL } & \text { Biomass-to-Liquid } & \text { HDPE } & \text { High-density Polyethylene } \\ \text { CHP } & \text { Combined Heat and Power } & \text { HVO } & \text { Hydrogenated Vegetable Oil } \\ \text { CNG } & \text { Compressed Natural Gas } & \text { HGV } & \text { Heavy Goods Vehicles } \\ \text { CC } & \text { Consolidation Centre } & \text { ICE } & \text { Internal Combustion Engine } \\ \text { CO } 2 \text { eq. } & \text { Carbon Dioxide Equivalent } & \text { LDPE } & \text { Light-density Polyethylene } \\ \mathrm{CONCAWE}^{-} & \text {Conservation of Clean Air and } & \text { LNG } & \text { Liquid Natural Gas } \\ \text { DC } & \text { Water in Europe } & & \\ \text { DME } & \text { Distribution Centre } & \text { QSRs } & \text { Quick Service Restaurants } \\ \text { FAME } & \text { Fatty Acid Methyl Ester } & \text { TTW } & \text { Tank-to-Wheel } \\ \text { FC } & \text { Fuel Cell } & \text { UCO } & \text { Used Cooking Oil } \\ \text { FFSC } & \text { Fast Food Supply Chain } & \text { WTT } & \text { Well-to-Tank }\end{array}$

\section{References}

4R Sustainability Inc. Conversion technology: A complement to plastic recycling. In: American Chemistry Council, editor. Sustainability. Portland2011. Banks C, Zhang Y. Technical Report: Optimising inputs and outputs from anaerobic digestion processes. Defra Project Code WR0212. London: Defra; 2010. Banks CJ, Salter AM, Heaven S, Riley K. Energetic and environmental benefits of co-digestion of food waste and cattle slurry: A preliminary assessment. Resources, Conservation and Recycling. 2011;56:71-9.

BioDME. Funding. Stockholm: BioDME; 2012.

Bioenergy2020+. Status of 2nd Generation Biofuels Demonstration Facilities. In: IEA, editor. IEA Taks 39. Graz: IEA; 2013.

Burger King. Burger King Introduces New Satisfries, Great Tasting Crinkle-Cut, Reduced Fat, Reduced Calorie French Fries. In: King B, editor. News \& Press. Miami: Burger King; 2013.

C-Tech Innovation Ltd. United Kingdom Food and Drink Processing Mass Balance. Chester2004. Cope E. Howard Tennens Environmental. Logistics Carbon Reduction Conference 2011. London: Freight Transport Association; 2011.

DAF Trucks Ltd. Interview at the "Commercial Motor Live 2013 ". In: Rowlinson K, editor. Millbrook2013.

Damartzis T, Zabaniotou A. Thermochemical conversion of biomass to second generation biofuels through integrated process design-A review. Renewable and Sustainable Energy Reviews. 2011;15:366-78.

DECC. Road transport energy consumption at regional and local authority level. In: DECC, editor. Statistical data set. London2013.

DECC. 2014 Government GHG Conversion Factors for Company Reporting: Methodology Paper for Emission Factors. In: Defra, editor. London: Crown; 2014a.

DECC. RHI Evidence Report: Biopropane for Grid Injection. Assessment of the Market, Renewable Heat Potential, Cost, Performance and Characteristics of Biopropane for Gas Grid Injection. In: DECC, editor. London: Crown; 2014b.

DECC. Table 4.1.3 Typical retail prices of petroleum products 1954 to 2015. In: Change DoEC, editor. Quarterly Energy Prices. London2015.

628 Defra. Food Statistics Pocketbook 2011. (in year update). London: Crown; 2011. 
Defra. Food statistics pocketbook 2013: chart data. In: Defra, editor. Statistics - national statistics.

630 London: Crown; 2013a.

631 Defra. Measuring and reporting environmental impacts: guidance for businesses. In: Defra, editor. London: Crown; 2013b. DESTA Consortium. DESTA Project. DESTA; 2014. p. DESTA SOFC APU Objectives.

DfT. Renewable Transport Fuel Obligation statistics: period 5, 2012/13, report 4 In: RTFO, editor. London: DfT; 2013a. DfT. RTFO Guidance Part Two: Carbon and Sustainability Guidance In: DfT, editor. 6.1 ed. London: Crown; 2013b. p. 55.

E4Tech, Concepto. Biofuels carbon calculator. In: Transport Df, editor. 6.0 ed. London2013.

Edwards R, Larive J-F, Rickheard D, Weindorf W. Well-to-tank Appendix 2 - Version 4.a. In: ((IET)

IfEaT, editor. Summary of energy and GHG balance of individual pathways. 4 ed. Petten: IET; 2014.

Elkington J. Partnerships from cannibals with forks: The triple bottom line of 21st-century business. Environmental Quality Management. 1998;8:37-51.

Ellen MacArthur Foundation. Towards the Circular Economy Vol.2: opportunities for the consumer goods sector. In: Foundation EM, editor. Circular Economy Reports. 1 ed: Ellen MacArthur Foundation; 2013.

Environmental Audit Committee. A Green Economy - Twelfth Report of Session 2010-12. In: House of Commons, editor. London: House of Commons; 2012.

European Commission. Directive 98/70/EC relating to the quality of petrol and diesel fuels and amending Directive 2009/28/EC on the promotion of the use of energy from renewable sources. Brussels: European Commission; 2011.

651 European Commission. Directive 2009/28/EC of the European Parliament and of the Council of 23

652 April 2009 on the promotion of the use of energy from renewable sources and amending and 653 subsequently repealing Directives 2001/77/EC and 2003/30/EC (Text with EEA relevance). Brussels: 654 European Commission; 2013. Freight Transport Association. Facts and Figures In: FTA, editor. Logistics Carbon Reduction Conference 2011. London: FTA; 2011. FRPERC, The Grimpsby Institute, University of Bristol. Fostering The Development Of Technologies And Practices To Reduce The Energy Inputs Into The Refrigeration Of Food. Sector Focus Transport2010. 112.

Gas Vehicle Hub. Map UK Gas Refuelling Facilities. London: GVH; 2014.

Google Maps. Map of the UK. 2013.

Gustavsson J, Cederberg C, Sonesson U, Otterdijk Rv, Meybeck A. Global Food Losses and Food Waste. In: FAO, editor. extent, causes and prevention. Rome: FAO; 2011.

Heaven S, Salter AM, Banks CJ. Integration of on-farm biodiesel production with anaerobic digestion to maximise energy yield and greenhouse gas savings from process and farm residues. Bioresource Technology. 2011;102:7784-93.

Hill N, Venfield H, Dun C, James K. Greenhouse gas conversion factors for company reporting 2013: methodology paper for emission factors. In: Defra D, editor. London: Crown; 2013.

Hollins O. Overview of Waste in the UK Hospitality and Food Service Sector. In: WRAP, editor. An overview of waste in the UK hospitality and food service sector. Banbury: WRAP; 2013. Houses of Parliament. Anaerobic Digestion. In: Parliamentary Office of Science \& Technology, editor. PostNote. London: Parliamentary; 2011.

Houses of Parliament. Lords to question Tesco, Waitrose and waste companies on food waste. In: Committee LS, editor. Food Waste Prevention. London: Crown; 2013. IBISWorld. Take-Away, Fast Food Restaurants in the UK: Market Research Report. Market Research. London: IBISWorld; 2013. 
679 Kaminsky W, Predel M, Sadiki A. Feedstock recycling of polymers by pyrolysis in a fluidised bed.

680 Polymer Degradation and Stability. 2004;85:1045-50.

681 KFC. Reducing Carbon Footprint. Sustainability: KFC; 2012. Lin Y, Wang D, Li Q, Huang L. Kinetic study of mesophilic anaerobic digestion of pulp paper sludge. Biomass and Bioenergy. 2011;35:4862-7. Magnusson $M$, Alvfors P. Biogas from mechanical pulping industry: Potential improvement for increased biomass vehicle fuels. Proccedings of ECOS 2012: The 25th international conferens on efficiency, cost, optimization, simulation and environmental impact of energy systems 2012. McDonald's. Building a Better Business Through Effective Environmental Practices Around the World. In: McDonald's, editor. Global Best of Green 20122012. p. 9.

Mercedes-Benz. Interview at the "UK Biomethane and Gas Vehicle Conference". In: Blake N, editor. London2013.

Michaud J-C, Farrant L, Jan O, Kjær B, Bakas I. Environmental benefits of recycling - 2010 update. In: WRAP, editor. Banbury: WRAP; 2010.

NNFCC. NNFCC AD Plant Map. In: The National Non-Food Crops Centre, editor. York: NNFCC; 2012. Ordnance Survey. Points of Interest. In: Crown, editor. Southampton2014.

Panwar NL, Kothari R, Tyagi VV. Thermo chemical conversion of biomass - Eco friendly energy routes. Renewable and Sustainable Energy Reviews. 2012;16:1801-16.

Rintala JA, Puhakka JA. Anaerobic treatment in pulp- and paper-mill waste management: A review. Bioresource Technology. 1994;47:1-18.

Saica Natur. Interview. In: Flores R, editor. Barcelona: Saica; 2012.

Searates.com. Transit Time / Distance calculator. London: Farnel Capital Inc.; 2013.

Sekab. ED95 - The Green Biofuel for Heavy Transport. In: Sekab, editor. Biofuel. Örnsköldsvik: Sekab; 2013.

Siemens. Range of eHighway applications. In: Siemens, editor. Electric-Powered HGV Traffic. Munich: Siemens; 2014.

SITA UK. SITA UK, subsidiary of SUEZ ENVIRONNEMENT, and Cynar PIc, sign a landmark recycling technology agreement for the conversion of end of life plastic (ELP) into diesel. Press Releases2011. Smith A, Watkiss P, Tweddle G, McKinnon PA, Browne PM, Hunt A, et al. The Validity of Food Miles as an Indicator of Sustainable Development: Final report In: AEA Technology Environment, editor.: DEFRA; 2005.

Sunde K, Brekke A, Solberg B. Environmental Impacts and Costs of Hydrotreated Vegetable Oils, Transesterified Lipids and Woody BTL-A Review. Energies. 2011;4:845-77.

Themelis NJ, Mussche C. 2014 Energy and Economic Value of Municipal Solid Waste (Msw), Including Non-Recycled Plastics (Nrp), Currently Landfilled In The Fifty States. New York: Columbia University; 2014. p. 24.

TOPSOE. METSOFC project EU FP7 Collaborative Project2010.

Vision Industries Corporation. Vision Tyrano Product Overview. Gardena2012.

Volvo Trucks. Interview at the "NEC Commercial Vehicle Show". In: Cattley R, editor.

Birmingham2013.

WRAP. The Composition of Waste Disposed of by the UK Hospitality Industry. Banbury: WRAP; 2011. 